УДК 553.493:550.42

\title{
МИНЕРАЛОГИЯ, ГЕОХИМИЯ И ГЕНЕЗИС РЕДКОМЕТАЛЛЬНОГО Zr-Nb-Hf-Ta-P3Э-Ga ОРУДЕНЕНИЯ В ПЛАСТЕ ХХХ МИНУСИНСКОГО БАССЕЙНА
}

\author{
Вергунов Алексей Викторович1, \\ alexeivergunov@rambler.ru
}

\author{
Арбузов Сергей Иванович1, \\ siarbuzov@mail.ru
}

\author{
Еремеева Влада Владиславовна', \\ vlada.eremeeva1996@yandex.ru \\ 1 Национальный исследовательский Томский политехнический университет, \\ Россия, 634050, г. Томск, пр. Ленина, 30.
}

\begin{abstract}
Актуальность исследования обусловлена необходимостью оценки влияния вулканогенного пирокластического материала на формирование геохимического фона редких элементов в угле.

Цель: изучить минералогические и геохимические особенности углей и пород пласта XXX Минусинского угольного бассейна. Объекты: угли и породы пласта XXX Минусинского бассейна.

Методы: опробование угольного пласта XXX Минусинского бассейна; химический состав определен методами массспектрометрии с индуктивно связанной плазмой (ICP-MS), атомно-эмиссионной спектрометрии с индуктивно связанной плазмой (ICP-AES), инструментальным нейтронно-активационным анализом (ИНАA); минеральный состав изучен методами оптической микроскопии, петрографрического анализа, сканирующей электронной микроскопии, рентгеновской дифррактометрии.

Результаты. Выполнены комплексные минералого-геохимические исследования редкометалльного Zr-Nb-Hf-Ta-P3Э-Ga opyденения в пласте XXX-XXXа Изыхского месторождения Минусинского бассейна. В золе угля максимальное содержание Zr coставляет 1,4 \%, Nb-0,26 \%, Hf - 164 г/m, Ta - 21,2 2/m, суммы P3Э - 0,8 \%, Ga - 226 г/m. Рудное вещество главным образом сконцентрировано в тонкодисперсной минеральной фразе, представленной преимущественно Zr-Nb-Ti-Fe оксидами, сложными $\mathrm{Nb-Zr-P}$ силикатами, редкоземельными фосфратами (монацит, ксенотим). Установлена связь аномальных концентраций редких металлов с внутрипластовым породным прослоем. В минеральном составе породного прослоя преобладает каолинит (68,9 \%), меньше распространены квари (11,0 \%), калиевые полевые шпаты (7,0 \%) и альбит (5,6 \%). Установлена вулканогенно-пирокластическая природа породного прослоя и определен его первичный состав как пантеллерит-комендитовый. Подобный по составу породный прослой, с которым связано редкометалльное оруденение в углях, известен в углях кемеровской свиты Кузбасса того же возраста. Комплексное Zr-Nb-Hf-Ta-P3Э-Ga оруденение в углях Кузнецкого и Минусинского бассейна, связанное с вулканогенной пирокластикой, свидетельствует о возможном проявлении активного кислого и щелочного вулканизма планетарного масштаба в период формирования углей и о возможности выявления подобного оруденения в углях пермского возраста других бассейнов.
\end{abstract}

\section{Ключевые слова:}

Уголь, угольный бассейн, редкометалльное оруденение, вулканогенная пирокластика, Минусинский бассейн.

\section{Введение}

В конце XX в. в Минусинском бассейне в пласте $\mathrm{XXX}$ изыхской свиты Изыхского месторождения было выявлено специфическое комплексное редкометалльное Zr-Nb-Hf-Ta-P3Э оруденение [1]. Согласно опубликованным данным, угли в нижней пачке пласта XXX содержат до 0,25 \% Р3Э, до $1 \% \mathrm{Zr}$, до 46 г/т Та. Высказано предположение о возможной связи этих аномалий с вулканогенной пирокластикой и о сходстве их с проявлением близкой по составу редкометалльной минерализации в углях пласта XI в кемеровской свите Кузбасса.

В настоящее время выявлено и изучено несколько комплексных редкометалльных месторождений в углях мира, состав которых схож с рудами Минусинского бассейна. Таковыми являются несколько месторождений в Китае [2-5] и России (Кузбасс) [6-8].

Для выяснения источника редких металлов в углях, а также возможной связи этого проявления с аналогичным месторождением в Кузбассе, были детально опробованы и изучены угли и породы пласта XXX Минусинского угольного бассейна.

\section{Геологическая характеристика объекта исследований}

Минусинский угольный бассейн располагается на юге Центрально-Сибирского региона. В геологическом плане он приурочен к одноименному прогибу, представляющему синклинальную структуру, вытянутую субмеридионально и ограниченную с запада, востока и юга структурами Кузнецкого Алатау, Восточного и Западного Саян [9]. Продуктивная толща сложена нижнекаменноугольными - верхнепермскими отложениями. Основными промышленными месторождениями для бассейна являются Черногорское, Изыхское и Бейское.

Изыхское месторождение расположено в центральной части угольного бассейна. В структурном плане месторождение выполняет коробчатую мульду с пологим дном, вытянутую в северо-западном направлении (рис. 1). 


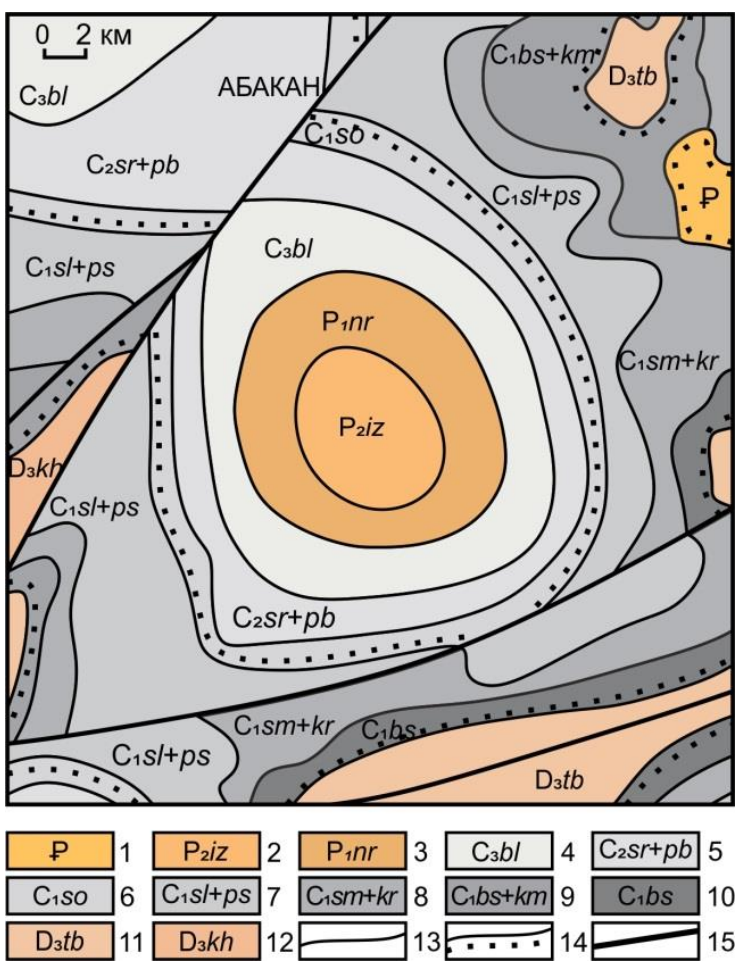

Pис. 1. Геологическая карта Изыхского месторождения [10]: 1 - палеогеновые образования; 2, 3 - пермские отложения: 2 - изыхская свита - алевролиты, аргиллиты, песчаники, пласты каменного угля (до 270 м), 3 - нарылковская свита - песчаники, алевролиты, аргиллиты, углистые аргиллиты, пласты каменного угля (до 360 м); 4-10 отложения карбонового возраста: 4 - белоярская свита, 5 - сарская, черногорская и побережная свиты объединенные, 6 - серпуховский ярус, соленоозерская свита, 7 - визейский ярус, соломенская ямкинская, байновская свиты объединенные, 8 - турнейский ярус, самохвальская и кривинская свиты объединенные, 9 - быстрянская, алтайская и камыштинская свиты объединенные, 10 - быстрянская свита; 11, 12 отложения девонского возраста: 11 - фаменский ярус, тубинская свита, 12 - франский ярус, кохайская свита; 13, 14 - геологические граниџы. 13 - согласного залегания, 14 - несогласного залегания; 15 - разрывные нарушения

Fig. 1. Geological map of the Izykh deposit [10]: 1 Paleogene sediments; 2, 3 -Permian sediments: 2 Izykhskaya suite - siltstones, mudstones, sandstones, coal seams (up to $270 \mathrm{~m}$ ), 3 - Narylkovskaya suite sandstones, siltstones, mudstones, carboniferous mudstones, coal seams (up to $360 \mathrm{~m}$ ); 4-10 - Carboniferous sediments: 4 - Beloyarskaya suite, 5 Sarskaya, Chernogorskaya and Poberezhnaya combined suites, 6 - Serpukhovian stage, Solenoozerskaya suite, 7 - Vizean stage, Solomenskaya, Yamkinskaya, Baynovskaya combined suites, 8 Tournaisian stage, Samokhvalskaya and Krivinskaya combined suites, 9 - Bystryanskaya, Altayskaya and Kamyshtinskaya combined suites, 10 - Bystryanskaya suite; 11, 12 - Devonian sediments: 11 Famennian stage, Tubinskaya suite, 12 - Frasnian stage, Kokhayskaya suite; 13, 14 - geologic boundaries: 13 - concordant bedding, 14 - disconcordant bedding; 15 - faults

\begin{tabular}{|c|c|c|c|}
\hline$\stackrel{\sqrt[\sigma]{5}}{\stackrel{\oplus}{0}}$ & $\begin{array}{l}\frac{5}{0} \\
\stackrel{\mathbb{\pi}}{5} \\
\text { L } \\
\end{array}$ & Литология & $\begin{array}{c}\text { Мощность, } \\
\text { м }\end{array}$ \\
\hline 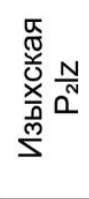 & $\begin{array}{l}X X X I \\
X X X \\
X X I X\end{array}$ & $=$ & $\begin{array}{c}5,0-6,8 \\
1,1-14,3\end{array}$ \\
\hline 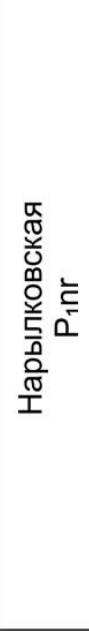 & $\begin{array}{l}\text { XXVIII } \\
\text { XXVII } \\
\text { XXVI } \\
\text { XXV } \\
\text { XXIV } \\
\text { XXIII }\end{array}$ & (n) & 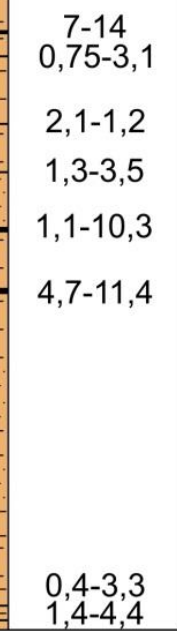 \\
\hline
\end{tabular}

1203

Pис. 2. Стратиграфический разрез пермских отложений Изыхского месторождения и положение в нём угольных пластов: 1 - песчаники, 2 - алеврито-песчаники, 3 - алевролиты, аргиллиты, 4 уголь

Fig. 2. Stratigraphic column of Permian sediments at Izykh deposit and coal-bearing layers location: 1 sandstones, 2 - silt-sandstones, 3 - siltstones, mudstones, 4 - coal

В Изыхской мульде вскрывается полный (1800 м) разрез продуктивной толщи от соленоозерской до изыхской свит. Больше половины разреза сложено алевролитами, в меньшей степени аргиллитами и песчаниками. Встречаются линзы сидеритов и конгломератов.

Нижняя граница Изыхской свиты $\left(\mathrm{P}_{2} \mathrm{iz}\right)$ проводится в основании междупластия, разделяющего пласты XXVIII и XXIX. Нижняя подсвита сложена мощной $(150$ м) безугольной пачкой, в которой отмечаются только единичные тонкие угольные пласты (XXIX) и пропластки, распространенные на ограниченной площади (рис. 2). Безугольная пачка залегает трансгрессивно на отложениях верхненарылковской подсвиты и сложена алевролитами и песчаниками. В 30 35 м от ее основания отмечается перерыв в объеме двух биостратиграфических горизонтов. Вверх по разрезу количество и мощность песчаниковых пачек увеличиваются. Верхняя подсвита (100-110 м) сложена алевролитами с прослоями аргиллитов, мелкозернистых песчаников и мощными пластами углей (XXX и XXXI). Общая мощность отложений 250-260 м.

Изыхская свита содержит два мощных угольных пласта XXX и XXXI. Пласт XXX сложного строения состоит из 5-7 угольных пачек мощностью от 0,1 до 
6,5 м суммарной мощностью 4,0-9,3 м, разделяемых породными прослоями общей мощностью от 0,35 до 2,95 м; на отдельных участках от него отщепляются угольные пачки, образуя самостоятельные пласты (ХХХа, ХХХб).

В угольном пласте ХХХа диагностировано три тонштейна. Они имеют небольшую мощность 1-2 см и равно удалены друг от друга ( 30 см). Угольный пласт XXX содержит два тонштейна. Мощность каждого из прослоев составляет 1 см. Тонштейны находятся на расстоянии 35 см друг от друга (рис. 3).

Особый интерес представляет междупластие XXXа и XXX пластов. Это мощный (45 см) прослой алевролита. Прослой имеет повышенную радиоактивность (25 мкР/ч)
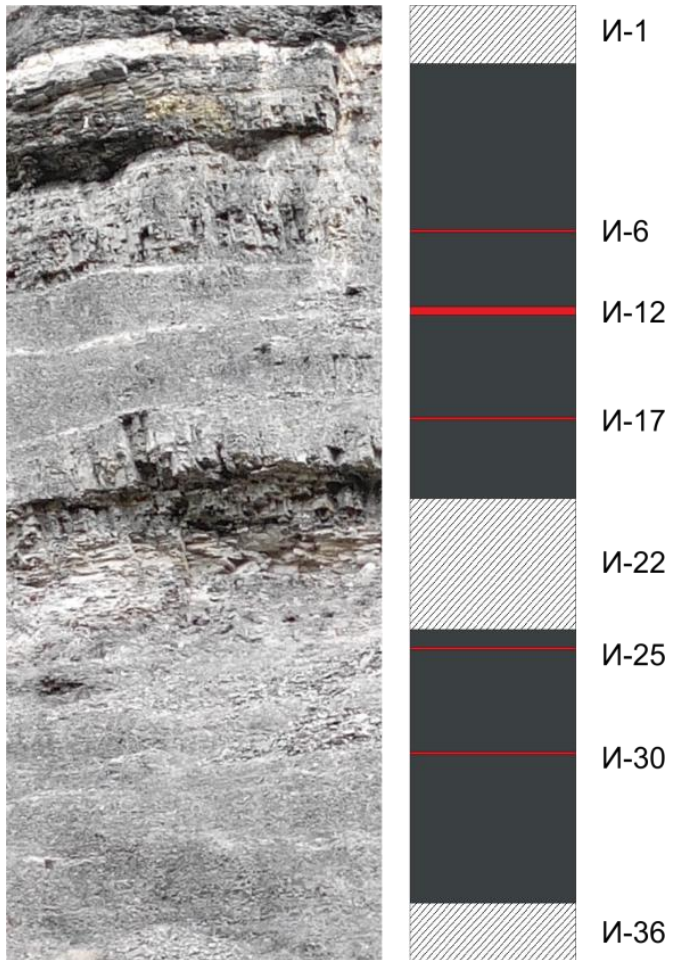

Рис. 3. Положение породных прослоев в угольных пластах ХХХа и ХХХ Изыхского месторождения

Fig. 3. Location of intraformational seams in the coal beds $X X X a$ and XXX, Izykh deposit

\section{Методика исследований}

Пробы отбирались в горных выработках на Изыхском угольном разрезе летом 2016 и 2018 гг. Опробование проводилось бороздовым методом, при сечении борозды $15 \times 5$ см. Длина секции опробования составила 1-45 см в зависимости от степени однородности пластов. Также были опробованы кровля, почва пластов и внутрипластовые породные прослои. Всего было отобрано 36 проб.

При выполнении исследования применялся комплекс современных методов нейтронно-активационного анализа (ИНАА), масс-спектрометрии с индуктивносвязанной плазмой (ICP-MS) и атомно-эмиссионной спектрометрии с индуктивно связанной плазмой (ICPAES).
ИНАА осуществлялся в ядерно-геохимической лаборатории на исследовательском ядерном реакторе ИРТ-Т ТПУ (аналитик А.Ф. Судыко). Определение содержания химических элементов в пробах осуществлялось без предварительного концентрирования для исключения возможности уменьшения концентрации элементов при озолении.

Исследования методами ИСП-МС и ИСП-АЭС произведены в аналитическом центре Дальневосточного геологического института ДВО РАН (исполнитель Н.В. Зарубина). Определение содержания малых элементов выполнено с использованием разложения сплавлением с метаборатом лития и кислотного разложения $\left(\mathrm{HClO}_{4}+\mathrm{HNO}_{3}+\mathrm{HF}\right)$. Анализ углевмещающих пород проведен с использованием двух схем разложения. Для проб угля применялся метод вскрытия без предварительного озоления с использованием кислотного разложения.

В табл. 1 показана сравнительная оценка результатов элементного анализа, полученного методами ИСП-МС и ИНАА. Анализ данных таблицы подтвердил удовлетворительную сходимость результатов.

Главные породообразующие элементы (Al, Ti, Fe, $\mathrm{Ca}, \mathrm{Mg}, \mathrm{K}, \mathrm{Na}, \mathrm{P})$ определены с помощью ИСП-АЭС. Определение содержания $\mathrm{H}_{2} \mathrm{O}$, ППП, $\mathrm{SiO}_{2}$ осуществлялось методом гравиметрии.

Таблица 1. Сравнение результатов определения содержания химических элементов методами ИСП-МС и ИНАА, г/m

Table 1. Comparison of chemical elements measurement by ICP-MS and INAA, ppm

\begin{tabular}{|c|c|c|c|c|c|}
\hline \multirow{3}{*}{$\begin{array}{l}\text { Элементь } \\
\text { Elements }\end{array}$} & \multicolumn{2}{|l|}{ И-21 } & \multicolumn{3}{|c|}{ И-22 } \\
\hline & \multirow{2}{*}{\begin{tabular}{|c|} 
ICP-MS \\
кислотное \\
разложение \\
acid digestion
\end{tabular}} & \multirow[b]{2}{*}{ INAA } & \multicolumn{2}{|c|}{ ICP-MS } & \multirow[b]{2}{*}{ INAA } \\
\hline & & & \begin{tabular}{c|} 
кислотное \\
разложение \\
acid digestion
\end{tabular} & $\begin{array}{c}\text { разложение } \\
\text { сплавлением } \\
\text { fusion digestion }\end{array}$ & \\
\hline $\mathrm{Sc}$ & 5,28 & 5,32 & 6,92 & 6,90 & 8,10 \\
\hline $\mathrm{Cr}$ & 55,1 & 63,7 & 16,1 & 53,7 & 36,2 \\
\hline $\mathrm{Co}$ & 20,7 & 26,1 & 10,2 & 12,1 & 10,5 \\
\hline $\mathrm{Zn}$ & 358 & 425 & 203 & 216 & 311 \\
\hline $\mathrm{Rb}$ & 3,95 & 4,65 & 18,8 & 12,5 & 17,9 \\
\hline $\mathrm{Sr}$ & 83,6 & $<40$ & 128 & 116 & $<40$ \\
\hline $\mathrm{Ba}$ & 72,4 & 60,9 & 289 & 262 & 348 \\
\hline $\mathrm{La}$ & 137 & 141 & 110 & 100 & 115 \\
\hline $\mathrm{Ce}$ & 282 & 243 & 243 & 223 & 214 \\
\hline $\mathrm{Nd}$ & 126 & 93,1 & 101 & 109 & 90,6 \\
\hline $\mathrm{Sm}$ & 24,2 & 30,6 & 23,4 & 22,5 & 36,5 \\
\hline $\mathrm{Eu}$ & 2,45 & 2,64 & 2,23 & 2,19 & 2,56 \\
\hline $\mathrm{Tb}$ & 3,93 & 5,08 & 3,49 & 3,39 & 3,99 \\
\hline $\mathrm{Yb}$ & 24,7 & 25,4 & 8,78 & 9,18 & 10,3 \\
\hline $\mathrm{Lu}$ & 3,72 & 3,79 & 1,24 & 1,28 & 1,44 \\
\hline Hf & 25,6 & 26,9 & 26,6 & 27,6 & 35,5 \\
\hline $\mathrm{Ta}$ & 2,20 & 2,37 & 6,98 & 5,97 & 8,26 \\
\hline Th & 7,49 & 6,08 & 21,7 & 18,8 & 25,9 \\
\hline $\mathrm{U}$ & 3,10 & 2,47 & 5,99 & 5,89 & 8,04 \\
\hline
\end{tabular}

Определение содержания $\mathrm{Hg}$ в образцах выполнено методом беспламенной абсорбции на приборе РА915+ с пиролитической приставкой ПИРО-915 (метод пиролиза). Диапазон измерений для массовой доли ртути в образцах колеблется от $10^{-3}$ до 10 г/т.

Для изучения структурно-текстурных особенностей, минерального состава, характера органических 
остатков неугольных прослоев применялся петрографический анализ.

Исследование состава минерального вещества породных прослоев, в том числе глинистых минералов, произведено методом рентгенофазового анализа (РФА). РФА был проведен на дифрактометре Bruker D2 Phaser в МИНОЦ «Урановая геология» в отделении геологии ТПУ (исполнитель А.В. Вергунов).

Изучение микроминеральных форм элементов в углях и золах углей производилось на сканирующем электронном микроскопе (CЭM) Hitachi S-3400N в МИНОЦ «Урановая геология» в отделении геологии ТПУ. Состав включений устанавливался с помощью энерго-дисперсионного спектрометра Bruker XFlash 4010/5010 для проведения рентгеноспектрального анализа. Исследование проб выполнялось в режиме низкого вакуума с детектором обратно-рассеянных электронов.

\section{Результаты исследований и их обсуждение}

\section{Химический состав угля и золы угля}

Среднее содержание химических элементов в углях и золе угля XXXа и XXX пластов приведено в табл. 2. От кларка [11] угли, а также золы углей обоих пластов отличаются высоким содержанием РЗЭ, Ве, Ni, Zn, Ga, Se, Sr, Y, Zr, Nb, Mo, Cd, Sn, Ba, Hf, Ta, W, $\mathrm{Pb}, \mathrm{Th}$.

В отдельных пробах угля содержание некоторых из указанных химических элементов может достигать аномально высоких значений. Например, концентрация циркония в угле достигает 0,2 \%, а ниобия - 293 г/т. Содержание бериллия достигает 9,6 г/т, галлия 44 г/т, иттрия - 212 г/т, олова - 21 г/т, Р3Э - 730 г/т, гафния - 27 г/т, тантала -14 г/т, тория -35 г/т. Все аномалии обнаружены в угле, находящемся непосредственно над или под породным прослоем, разделяющим угольные пласты XXXа и XXX. Прослой имеет повышенную радиоактивность - 25 мкР/ч и отличается аномальным содержанием литофильных элементов, таких как Li, Be, Ga, Y, Zr, Nb, Sn, P3Э, Hf Та, Тh и U (табл. 5).

Приведенные данные позволяют установить $\mathrm{Nb}$ Ta-Zr-Hf-Y-P3Э-Ga оруденение с группой попутных литофильных металлов, таких как галлий, литий, олово и др., в пластах XXXа и ХXX. Руды схожего состава выявлены и изучены в Кузбассе [8]. Также подобное оруденение известно в углях Китая $[2,3]$.

Концентрация ниобия в среднем для золы угля изученных пластов составляет 320 г/т. Для золы угля пласта XXXа этот показатель составил 262 г/т, а для XXX - 411 г/т. Распределение ниобия в разрезе неравномерно. Наблюдается явная приуроченность высоких концентраций в углях к границе с породным прослоем (рис. 4). Зона обогащения над прослоем больше по мощности нежели под ним. Однако содержание $\mathrm{Nb}$ под прослоем достигает 2625 г/т, против 1786 г/т для золы угля над ним. В самом же породном прослое концентрация ниобия составила 114 г/т.
Таблица 2. Содержание химических элементов в углях и золах углей, г/m

Table 2. Trace element concentrations in coals and coal ashes, ppm

\begin{tabular}{|c|c|c|c|c|c|c|c|c|c|}
\hline \multirow{3}{*}{$\begin{array}{l}\text { Элементы } \\
\text { Elements }\end{array}$} & \multicolumn{4}{|c|}{ Пласт/Coal bed } & \multirow{2}{*}{\multicolumn{2}{|c|}{$\begin{array}{c}\text { Оба пласта } \\
\text { Both coal } \\
\text { beds }\end{array}$}} & \multirow{2}{*}{\multicolumn{2}{|c|}{$\begin{array}{l}\text { Кларк }^{1} \\
\text { Clark }^{1}\end{array}$}} & \multirow{3}{*}{$\begin{array}{l}\mathrm{KK}^{2} \\
\mathrm{CC}^{2}\end{array}$} \\
\hline & \multicolumn{2}{|c|}{ XXXa } & \multicolumn{2}{|c|}{ XXX } & & & & & \\
\hline & $\begin{array}{c}\text { уголь } \\
\text { coal }\end{array}$ & $\begin{array}{c}\text { зола } \\
\text { ash }\end{array}$ & $\begin{array}{c}\text { уголь } \\
\text { coal }\end{array}$ & $\begin{array}{c}\text { зола } \\
\text { ash }\end{array}$ & $\begin{array}{c}\text { уголь } \\
\text { coal }\end{array}$ & $\begin{array}{c}\text { зола } \\
\text { ash }\end{array}$ & $\begin{array}{c}\text { уголь } \\
\text { coal }\end{array}$ & $\begin{array}{c}\text { зола } \\
\text { ash }\end{array}$ & \\
\hline $\mathrm{Li}$ & 4,6 & 46,3 & 8,2 & 39,9 & 6,0 & 43,8 & 12 & 66 & 0,7 \\
\hline $\mathrm{Be}$ & 3,4 & 40,3 & 4,2 & 37,7 & 3,7 & 39,3 & 1,6 & 9,4 & 4,2 \\
\hline $\mathrm{Sc}$ & 2,2 & 23,4 & 1,6 & 12,3 & 2,0 & 19,0 & 3,9 & 23 & 0,8 \\
\hline $\mathrm{V}$ & 28,1 & 276 & 11,5 & 73,6 & 21,6 & 196 & 25 & 155 & 1,3 \\
\hline $\mathrm{Cr}$ & 16,5 & 170 & 14,1 & 98,7 & 15,5 & 142 & 16 & 100 & 1,4 \\
\hline $\mathrm{Co}$ & 5,1 & 52,8 & 2,3 & 18,2 & 4,0 & 39,2 & 5,1 & 32 & 1,2 \\
\hline $\mathrm{Ni}$ & 31,1 & 334 & 12,1 & 100 & 23,6 & 242 & 13 & 76 & 3,2 \\
\hline $\mathrm{Cu}$ & 11,8 & 130 & 11,0 & 79,5 & 11,5 & 110 & 16 & 92 & 1,2 \\
\hline $\mathrm{Zn}$ & 58,3 & 560 & 85,8 & 647 & 69,1 & 594 & 23 & 140 & 4,2 \\
\hline $\mathrm{Ga}$ & 5,2 & 53,9 & 10,5 & 64,7 & 7,3 & 58,2 & 5,8 & 33 & 1,8 \\
\hline $\mathrm{Ge}$ & 1,5 & 14,0 & 1,7 & 15,9 & 1,6 & 14,8 & 2,2 & 15 & 1,0 \\
\hline As & 4,3 & 45,0 & 3,3 & 22,4 & 3,9 & 36,1 & 8,3 & 47 & 0,8 \\
\hline $\mathrm{Se}$ & 1,4 & 14,0 & 2,6 & 19,0 & 1,9 & 15,9 & 1,3 & 8,8 & 1,8 \\
\hline $\mathrm{Br}$ & 0,7 & 8,5 & 0,6 & 4,7 & 0,7 & 7,0 & 5,2 & 32 & 0,2 \\
\hline $\mathrm{Rb}$ & 1,6 & 15,4 & 6,1 & 33,0 & 3,4 & 22,3 & 14 & 79 & 0,3 \\
\hline $\mathrm{Sr}$ & 266 & \begin{tabular}{|l}
2859 \\
\end{tabular} & 81,6 & 583 & 194 & 1965 & 110 & 740 & 2,7 \\
\hline $\mathrm{Y}$ & 25,6 & 224 & 34,2 & 273 & 29,0 & 243 & 8,4 & 51 & 4,8 \\
\hline $\mathrm{Zr}$ & 252 & 2167 & 280 & 2122 & 263 & 2149 & 36 & 210 & 10,2 \\
\hline $\mathrm{Nb}$ & 31,2 & 262 & 42,4 & 411 & 35,6 & 320 & 3,7 & 20 & 16,0 \\
\hline Mo & 4,5 & 49,5 & 3,8 & 33,3 & 4,2 & 43,2 & 2,2 & 14 & 3,1 \\
\hline $\mathrm{Cd}$ & 0,45 & 4 & 0,37 & 2,8 & 0,42 & 3,8 & 0,22 & 2 & 3,2 \\
\hline $\mathrm{Sn}$ & 1,0 & 10,3 & 2,8 & 9,5 & 1,7 & 10,0 & 1,1 & 6,4 & 1,6 \\
\hline $\mathrm{Sb}$ & 1,0 & 9,8 & 0,77 & 7,3 & 0,88 & 8,8 & 0,92 & 6,3 & 1,4 \\
\hline $\mathrm{Te}$ & 0,09 & 0 & 0,07 & 0,48 & 0,08 & 0,81 & - & - & - \\
\hline $\mathrm{Cs}$ & 0,18 & 1,8 & 0,53 & 3,0 & 0,32 & 2,3 & 1 & 6,6 & 0,3 \\
\hline $\mathrm{Ba}$ & 228 & 2466 & 281 & 2017 & 249 & 2290 & 150 & \begin{tabular}{|l|}
940 \\
\end{tabular} & 2,4 \\
\hline $\mathrm{La}$ & 26,4 & 265 & 58,0 & 416 & 38,8 & 324 & 11 & 69 & 4,7 \\
\hline $\mathrm{Ce}$ & 49,5 & 484 & 119 & 850 & 76,6 & 628 & 23 & 130 & 4,8 \\
\hline $\operatorname{Pr}$ & 5,4 & 52,0 & 13,8 & 98,5 & 8,7 & 70,3 & 3,5 & 20 & 3,5 \\
\hline $\mathrm{Nd}$ & 21,5 & 207 & 54,0 & 386 & \begin{tabular}{|l|}
34,3 \\
\end{tabular} & 277 & 12 & 67 & 4,1 \\
\hline $\mathrm{Sm}$ & 3,8 & 35,5 & 9,0 & 65,4 & 5,8 & 47,3 & 2 & 13 & 3,6 \\
\hline $\mathrm{Eu}$ & 0,46 & .5 & 0,82 & 6,0 & 0,60 & 5,1 & 0,47 & 2,5 & 2,0 \\
\hline $\mathrm{Gd}$ & 3,9 & 36,4 & 7,9 & 59,6 & 5,5 & 45,5 & 2,7 & 16 & 2,8 \\
\hline $\mathrm{Tb}$ & 0,53 & 4,8 & 0,94 & 7,1 & \begin{tabular}{|l|}
0,69 \\
\end{tabular} & 5,7 & 0,32 & 2,1 & 2,7 \\
\hline Dy & 3,8 & 33,7 & 5,7 & 44,4 & 4,6 & 37,9 & 2,1 & 14 & 2,7 \\
\hline Ho & 0,88 & 7,7 & 1,2 & 9,4 & 1,0 & 8,4 & 0,54 & 4 & 2,1 \\
\hline $\mathrm{Er}$ & 2,9 & 25,5 & 3,7 & 29,1 & 3,2 & 26,9 & 0,93 & 5,5 & 4,9 \\
\hline $\mathrm{Tm}$ & 0,40 & 3,5 & 0,48 & 3,8 & 0,43 & 3,6 & 0,31 & 2 & 1,8 \\
\hline $\mathrm{Yb}$ & 3,0 & 27,0 & 3,6 & 28,4 & 3,3 & 27,6 & 1 & 6,2 & 4,4 \\
\hline $\mathrm{Lu}$ & 0,48 & 4,3 & 0,54 & 4,2 & 0,50 & 4,3 & 0,2 & 1,2 & 3,6 \\
\hline $\mathrm{Hf}$ & 3,7 & 34,0 & 6,4 & 39,7 & 4,8 & 36,2 & 1,2 & 8,3 & 4,4 \\
\hline $\mathrm{Ta}$ & 0,40 & 3,8 & 1,9 & 7,1 & 1,0 & 5,1 & 0,28 & 1,7 & 3,0 \\
\hline W & 2,0 & 24,8 & 1,5 & 12,8 & 1,8 & 20,1 & 1,1 & 6,9 & 2,9 \\
\hline $\mathrm{Au}$ & 0,0011 & 0,0134 & 0,0016 & 0,0146 & 0,0013 & 0,0138 & 0,0037 & 0,022 & 0,6 \\
\hline $\mathrm{Hg}^{3}$ & 149 & 1602 & 125 & 852 & 139 & 1307 & 100 & 750 & 0,2 \\
\hline $\mathrm{Tl}$ & 0,63 & 6,7 & 0,29 & 1,6 & 0,50 & 4,7 & 0,63 & 4,9 & 1,0 \\
\hline $\mathrm{Pb}$ & 8,8 & 90,1 & 18,2 & 67,6 & 12,5 & 81,3 & 7,8 & 47 & 1,7 \\
\hline Th & 3,6 & 38,3 & 6,9 & 35,7 & 4,9 & 37,3 & 3,3 & 21 & 1,8 \\
\hline $\mathrm{U}$ & 0,78 & 8,0 & 2,5 & 16,4 & 1,4 & 11,3 & 2,4 & 16 & 0,7 \\
\hline$\sum \mathrm{P} 3 Э / \sum \mathrm{REE}$ & 123 & 1191 & 278 & 2008 & 184 & 1512 & 60,1 & 353 & 4,3 \\
\hline
\end{tabular}

Примечание: - нет данных; 1 - кларк для углей по [11]; 2 - отношение среднего содержания в золе угля к кларку для золь углей (КK); 3 - мг/m; содержание $\mathrm{Hg}$ в золе получено путем пересчета содержания в угле.

Note: - no data; 1 - clark for coals [11]; 2 - ratio of the average concentration in the coal ash to the clark for coal ashes $(\mathrm{CC}) ; 3-\mathrm{ppb}, \mathrm{Hg}$ in the coal ash was recalculated from the coal. 
Среднее содержание тантала в золе угля составило 5,1 г/т. Для золы угля пласта ХХХа этот показатель составил 3,8 г/т, а для XXX - 7,1 г/т. Распределение тантала, как и ниобия, неравномерно и приурочено к породному прослою - междупластию. Концентрация тантала в указанном прослое составила 9,7 г/т, а в золе угля, находящегося непосредственно под партингом, - 21 г/т. Также значимая концентрация тантала $(17,9$ г/т) наблюдается в золе угля на контакте с тонштейном (рис. 4).

Концентрация циркония в золе угля пласта XXXа составила 2167 г/т, для XXX - 2122 г/т. Распределение циркония в разрезе схоже с распределением ниобия. Зона обогащения угля над прослоем мощнее и контрастнее, чем под ним. Наибольшая концентрация циркония наблюдается в золе угля, расположенного над прослоем, и составляет 14270 г/т. На удалении от породного междупластия концентрация циркония в золе угля уменьшается (5109 г/т), но по-прежнему остается повышенной. В самом же партинге концентрация циркония составила 1337 г/т.

Среднее содержание гафния в золе угля составило 36,2 г/т. Для золы угля пластов XXXа и XXX концентрация гафния - 34,0 г/Т и 39,7 г/т соответственно. Схемы распределения гафния и циркония схожи, что связано с геохимическим сродством этих элементов. Концентрация гафния в прослое составляет 41,7 г/т, в то время как в золе угля, расположенного выше партинга, достигает 164 г/т.
Концентрация галлия в золе угля составила 58,2 г/т. Распределение галлия в пласте неравномерно, аномальные концентрации приурочены к породному прослою. Концентрация галлия в прослое составила 64,5 г/т, наибольшая концентрация в золе угля 226 г/т.

Содержание радиоактивных элементов в углях пласта не является промышленно значимым, но играет важную роль при выявлении в углях редкометалльного оруденения подобного типа. Из-за повышенной радиоактивности в 25 мкР/ч представляется возможным выявлять редкометалльное оруденение при гамма-каротаже, а также при использовании полевого радиометрического оборудования в горных выработках.

Среднее содержание тория в золе угля составляет 37,3 г/т, урана - 11,3 г/т. Прослой содержит 30,4 г/т Th и 9,4 г/т U. B золе угля на контакте с партингом содержание тория достигает 51,6 г/т, урана - 15,1 г/т.

Среднее содержание РЗЭ (суммы лантаноидов) в золе угля составило 1191 г/т. Концентрация РЗЭ в прослое - 682 г/т. Участок пласта под прослоем обогащен РЗЭ в большей степени, концентрация в золе угля под партингом достигает 7418 г/т.

Среднее содержание иттрия в золе угля пластов XXXа и XXX составляет 243 г/т. Наибольшие концентрации иттрия приурочены к породному прослою, максимальные значения в золе угля достигают 1290 г/т. В самом же прослое концентрация составила 124 г/ .
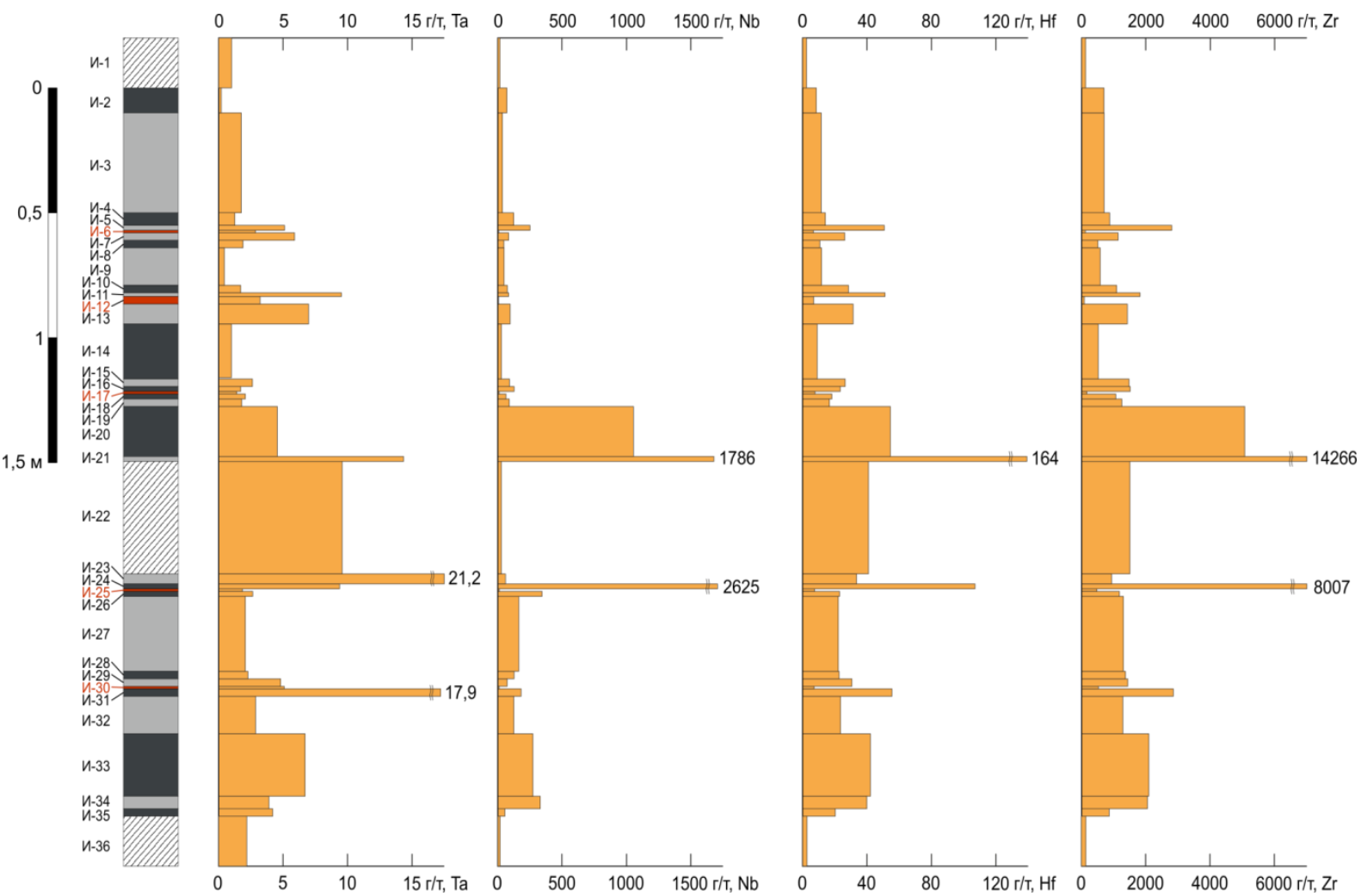

Puc. 4. Распределение Ta, Nb, Hf, Zr в золе угля в вертикальном разрезе пластов ХХХХ и XXX

Fig. 4. Distribution of Ta, Nb, $H f, Z r$ in coal ash in a vertical cross-section of the seams XXXa and XXX 
Таким образом, проведенные исследования показали, что угли и породные прослои в угольном пласте XXX и ХХХа отличаются аномально высокими содержаниями Zr, $\mathrm{Nb}, \mathrm{Hf}, \mathrm{Ta}, \mathrm{P} 3 Э$ и Ga. При этом наиболее обогащены этими элементами угли, приуроченные к породному прослоюмеждупластию, разделяющему угольные пласты ХХХа и $\mathrm{XXX}$, и в меньшей степени - к тонштейнам. Диагностика минералого-геохимических особенностей этого породного прослоя позволяет установить его природу и механизм влияния на геохимические особенности вмещающих углей.

Особенности минералогии породных прослоев и углей

При петрографических исследованиях породных прослоев под оптическим микроскопом установлено, что партинги представляют собой обломочную породу алевритовой размерности. Основная масса породы представлена глинистыми минералами, а также органическим веществом (рис. 5). В этой массе часто встречаются кристаллы полевых шпатов и кварца. В прослоях отсутствует стратификация зерен, расположение неориентированное. Зерна угловатые, следов окатанности не наблюдается.

В некоторых из изученных прослоев обнаружены вторичные структуры, образованные каолинитом. Каолинит в этих прослоях представлен в виде кристаллов, крупинок, псевдоморфоз по полевым шпатам и слюдам, а также в виде скрытокристаллической массы.
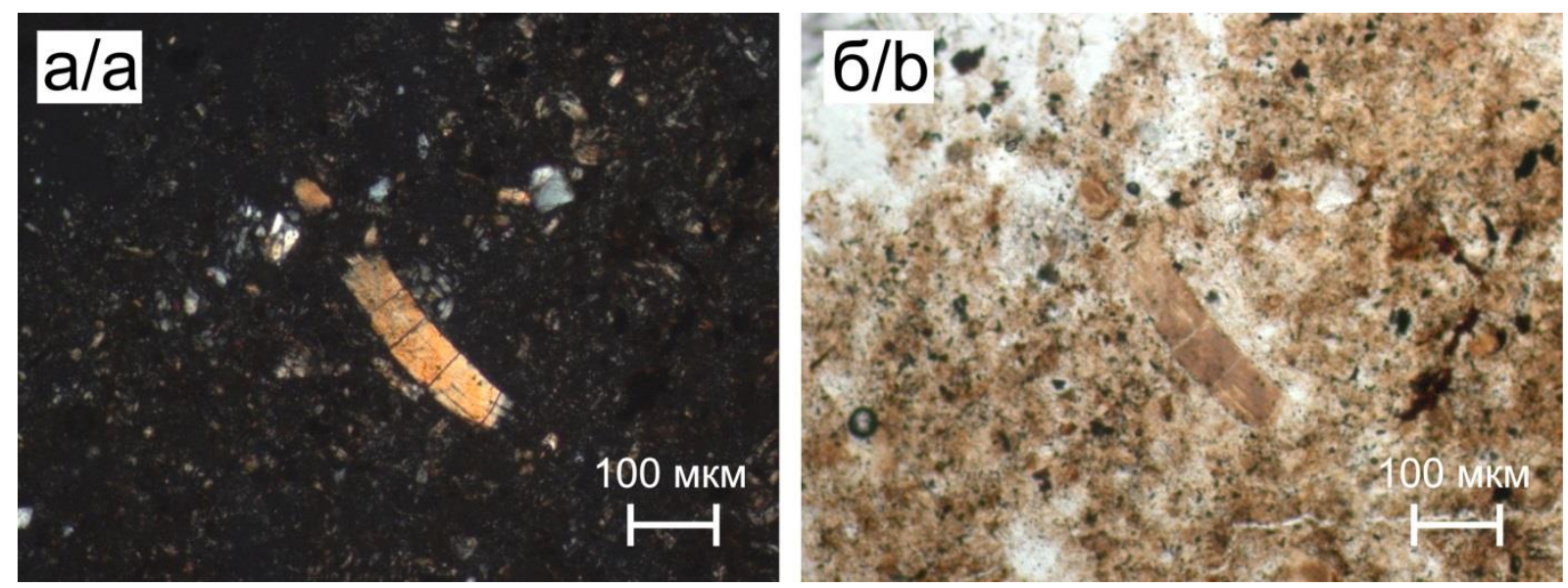

Pис. 5. Структура породы прослоя. Оптический микроскоп. а) николи скрещены; б) николи параллельны

Fig. 5. Structure of intraformational seams. Optical microscopy. a) crossed nicols; b) parallel nicols

Таблица 3. Минеральный состав изученных породных прослоев, \%

Table 3. Mineral composition of the studied intraformational seams, \%

\begin{tabular}{|l|c|c|c|c|c|c|c|c|}
\hline $\begin{array}{c}\text { Минерал } \\
\text { Мineral }\end{array}$ & И-1 & И-6 & И-12 & И-17 & И-22 & И-25 & И-30 & И-36 \\
\hline $\begin{array}{l}\text { Каолинит } \\
\text { Каolinite }\end{array}$ & 21,0 & 36,4 & 42,5 & 33,8 & 68,9 & 20,9 & 28,0 & 82,0 \\
\hline $\begin{array}{l}\text { Кварц } \\
\text { Quartz }\end{array}$ & 39,0 & 36,4 & 31,5 & 66,2 & 11 & 52,0 & 29,9 & 5,5 \\
\hline $\begin{array}{l}\text { КПШ } \\
\text { К-feldspar }\end{array}$ & - & - & 14,2 & - & 7 & 27,1 & 42,1 & 12,5 \\
\hline $\begin{array}{l}\text { Альбит } \\
\text { Albite }\end{array}$ & - & - & - & - & 5,6 & - & - & - \\
\hline $\begin{array}{l}\text { Мусковит } \\
\text { Мusсоvite }\end{array}$ & 28,1 & - & - & - & - & - & - & - \\
\hline $\begin{array}{l}\text { Хлорит } \\
\text { Сhlorite }\end{array}$ & 11,9 & - & - & - & - & - & - & - \\
\hline $\begin{array}{l}\text { Апатит } \\
\text { Араtite }\end{array}$ & - & 22,0 & 11,8 & - & 3,5 & - & - & - \\
\hline $\begin{array}{l}\text { Сидерит } \\
\text { Siderite }\end{array}$ & - & 5,2 & - & - & - & - & - & - \\
\hline $\begin{array}{l}\text { ССО } \\
\text { МL }\end{array}$ & - & - & - & - & 3 & - & - & - \\
\hline $\begin{array}{l}\text { Смектит } \\
\text { Smесtite }\end{array}$ & - & - & - & - & 1 & - & - & - \\
\hline & 100 & 100 & 100 & 100 & 100 & 100 & 100 & 100 \\
\hline
\end{tabular}

Примечание: $\mathrm{CCO}$ - смешаннослойные образования. Note: $M L$ - mixed-layer clay minerals.

Результаты рентгенофазового анализа подтверждают данные петрографических исследований (табл. 3). Породные прослои состоят из каолинита (21-68,9 \%) и кварца $(5,5-66,2 \%)$. В составе трех проб (И-6, И-12, И-22) диагностирован апатит (3,5-22 \%). В четырех пробах (И-12, И-22, И-25 и И-30) содержатся калиевые полевые шпаты (7-42,1 \%).

В ходе исследования был изучен микроминеральный состав породного прослоя - междупластия, и вмещающих его углей. В составе породного прослоя встречаются кристаллы полевых шпатов, каолинита, кварца, фторапатита.

Минералы циркония представлены его сложными $\mathrm{Nb}-\mathrm{Zr}-\mathrm{P}$ силикатами, а также цирконом. Кристаллы циркона имеют неправильную форму и, вероятно, были подвержены выщелачиванию в процессе преобразования исходного материала в условиях палеоболота (рис. 6, a). Встречаются сложные Nb-Zr-P силикаты, расположенные непосредственно на оксидах титана (рис. 6, б). Среди агрегатов оксида титана были обнаружены разности с примесью $\mathrm{Nb}$ (рис. 6, в).

В породном прослое лантаноиды представлены преимущественно фосфатами - монацитом (рис. 6, г). В породном прослое выявлены сульфиды (пирит, галенит, сфалерит). Встречаются зерна барита. Большинство сульфидов имеют почковидную форму.

Во вмещающем породный прослой угле выявлен гипс, целестин, барит. Такие образования описаны в приконтактовой зоне риолитового тонштейна Чарлстон Маск в Англии [12]. 
В угле, расположенном выше и ниже породного прослоя в приконтактовой зоне, обнаружены агрегаты Zr-Y фосфатов (рис. 7, a). Форма выделения минералов говорит о вторичном их образовании в процес- се перераспределения вещества, которое поступило из породного прослоя. Также в угле, расположенном под породным прослоем, часто встречаются агрегаты фосфатов РЗЭ в виде прожилков (рис. 7, б).
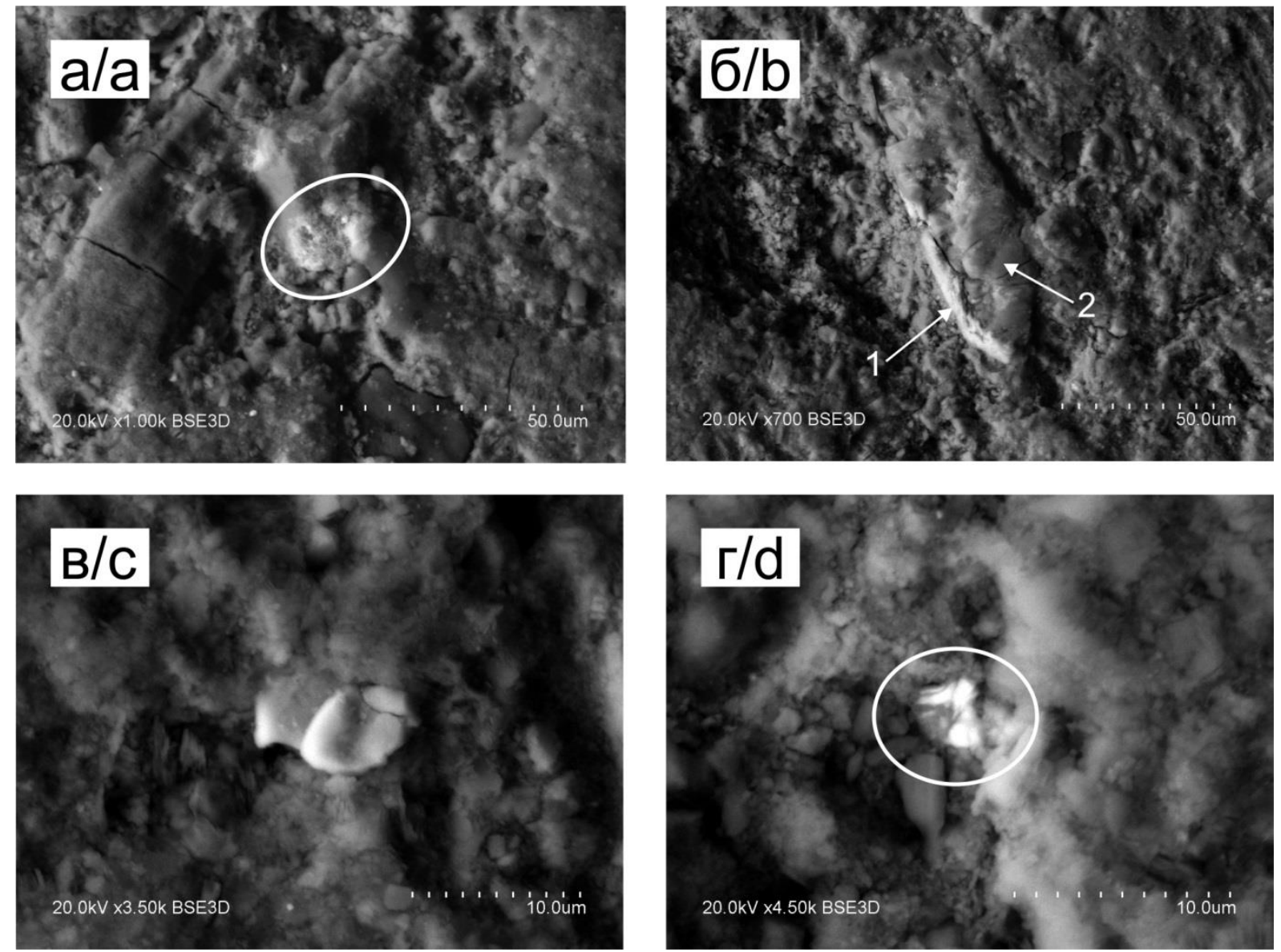

Pис. 6. а) кристаллы ичиркона в породном прослое; б) кристалл оксида титана (2) и агрегат Zr-Nb-P (1); в) кристалл оксида титана с примесью $\mathrm{Nb}$; г) кристалл монацита

Fig. 6. a) zircon crystals in intraformational seam; b) titanium oxide crystal (2) and Zr-Nb-P aggregate (1); c) Nb-doped titanium oxide crystal; d) monazite crystal
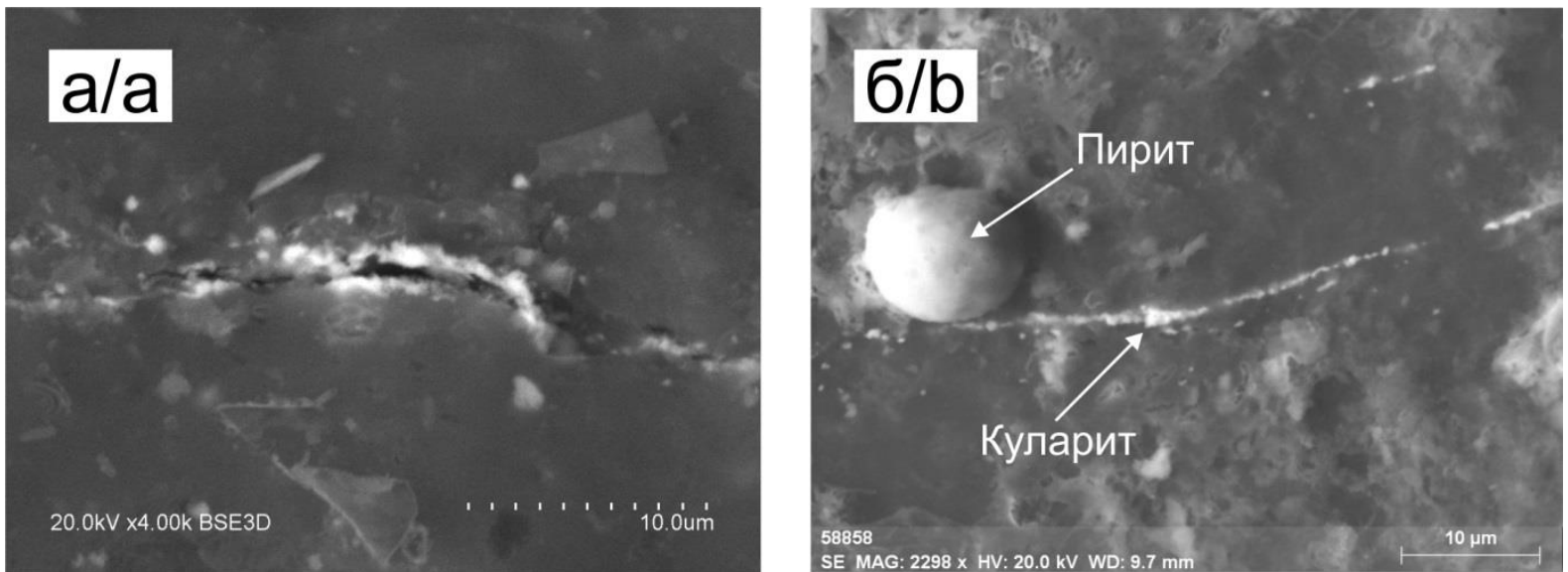

Pис. 7. а) агрегаты Zr-Y фосфата из угля над прослоем; б) прожилок куларита в угле непосредственно под прослоем

Fig. 7. a) Zr-Y phosphate aggregates from the coal above intraformational seam; b) cularite veinlet in the coal under intraformational seam 


\section{Геохимические особенности породных прослоев}

Изученные образцы различны по содержанию микроэлементов. В породных прослоях ХXX пласта (пробы И-30, И-25) отмечено повышенное относительно среднего состава глинистых сланцев содержание Be, Zn, Ga, Se, Zr, Mo, Ba, P3Э, Hf, Та. Также тонштейн (проба И-25) обогащен $\mathrm{Cu}, \mathrm{As}, \mathrm{Y}$, и $\mathrm{Nb}$, однако в тонштейне И-30 повышенного содержания этих элементов не отмечено (табл. 5).

По сравнению со средним составом глинистых сланцев в породном прослое-междупластии (проба И22) отмечены высокие концентрации $\mathrm{Li}, \mathrm{Be}, \mathrm{Cu}, \mathrm{Zn}$, $\mathrm{Ga}, \mathrm{Se}, \mathrm{Y}, \mathrm{Zr}, \mathrm{Nb}, \mathrm{Sn}, \mathrm{P} 3 Э, \mathrm{Hf}, \mathrm{Ta}, \mathrm{Pb}, \mathrm{Th}$ и U.

Породные прослои (тонштейны) пласта ХХХа также обогащены определенным набором элементов, по сравнению с составом глинистых сланцев. Так, в составе тонштейна И-17 обнаружены высокие концентрации $\mathrm{Be}, \mathrm{Cr}, \mathrm{Co}, \mathrm{Ni}, \mathrm{Cu}, \mathrm{Zn}, \mathrm{Ge}, \mathrm{As}, \mathrm{Se}, \mathrm{Y}, \mathrm{Zr}, \mathrm{Nb}$, Mo, Sn, Ba, P3Э, Hf, W, Au, Pb, Тh. Тонштейны И-12 и И-6 обогащены Li, Se, Y, Sn, Hf, Ta, Pb, Th и U.

Проба И-1, представляющая собой кровлю пласта $\mathrm{XXXa,} \mathrm{обогащена} \mathrm{Cr}, \mathrm{Ni}, \mathrm{Zn}, \mathrm{As}, \mathrm{Se}, \mathrm{Mo.}$ А проба И-36 (почва пласта XXX) обогащена Li, Ga, Se, Sn, Pb, Th.

Из изложенного видно, что исследованные породы обогащены различными группами химических элементов. Это связано с особенностями состава исходных пород, сформировавших изучаемые прослои. Предполагается, что этим материалом, сформировавшим внутриугольные прослои, служил вулканический пепел различного состава.

В табл. 4 приведен химический состав изученных породных прослоев, а также пород кровли и почвы. Содержание кремнезема в породных прослоях колеблется в пределах 20,0-49,8 \%, а глинозема - 4,0-27,8 \%

Таблица 4. Породообразующие оксиды (вес. \%) в углевмещающих породах и породных прослоях

Table 4. Rock-forming oxides (wt. \%) in coal-bearing rocks and intraformational seams

\begin{tabular}{|c|c|c|c|c|c|c|c|}
\hline $\begin{array}{c}\text { Оксид } \\
\text { Охіле }\end{array}$ & И-1 & И-6 & И-12 & И-17 & И-22 & И-25 & И-30 \\
\hline $\mathrm{SiO}_{2}$ & 47,1 & 34,0 & 34,7 & 20,0 & 49,8 & 38,5 & 41,0 \\
\hline $\mathrm{TiO}_{2}$ & 0,52 & 0,49 & 0,59 & 0,21 & 0,65 & 0,24 & 0,25 \\
\hline $\mathrm{Al}_{2} \mathrm{O}_{3}$ & 15,8 & 13,1 & 16,4 & 4,0 & 27,8 & 9,1 & 13,5 \\
\hline $\mathrm{Fe}_{2} \mathrm{O}_{3}$ & 6,2 & 0,48 & 0,81 & 0,72 & 0,86 & 0,96 & 0,69 \\
\hline $\mathrm{MnO}$ & 0,096 & 0,010 & 0,011 & 0,004 & 0,006 & 0,006 & 0,005 \\
\hline $\mathrm{CaO}$ & 0,83 & 6,18 & 3,61 & 0,34 & 1,58 & 0,31 & 0,26 \\
\hline $\mathrm{Mg} 0$ & 1,07 & 0,17 & 0,20 & 0,08 & 0,31 & 0,14 & 0,17 \\
\hline $\mathrm{K}_{2} \mathrm{O}$ & 1,14 & 0,33 & 0,85 & 0,23 & 0,71 & 0,55 & 2,54 \\
\hline $\mathrm{Na}_{2} \mathrm{O}$ & 0,36 & 0,16 & 0,18 & 0,09 & 0,37 & 0,20 & 0,19 \\
\hline $\mathrm{P}_{2} \mathrm{O}_{5}$ & 0,13 & 3,86 & 2,16 & 0,04 & 0,88 & 0,09 & 0,10 \\
\hline $\mathrm{H}_{2} \mathrm{O}$ & 2,42 & 4,59 & 4,6 & 7,8 & 3,2 & 5,31 & 4,32 \\
\hline $\mathrm{LOI} \mathrm{OI}$ & 23,9 & 36,4 & 35,6 & 66,3 & 13,6 & 44,4 & 36,5 \\
\hline${\mathrm{Cyмма} / \mathrm{Sum}_{2}}_{2} 99,6$ & 99,8 & 99,7 & 99,8 & 99,8 & 99,7 & 99,5 \\
\hline $\mathrm{TiO}_{2} / \mathrm{Al}_{2} \mathrm{O}_{3}$ & 0,033 & 0,037 & 0,036 & 0,053 & 0,023 & 0,027 & 0,018 \\
\hline $\mathrm{SiO}_{2} / \mathrm{Al}_{2} \mathrm{O}_{3}$ & 2,99 & 2,60 & 2,12 & 5,01 & 1,79 & 4,26 & 3,04 \\
\hline
\end{tabular}

Среди изученных пород выделяются три пробы с повышенным содержанием фосфора. Из них две пробы, расположенные в верхней пачке (пласт XXXa): И-6 и И-12, содержат 3,86 и 2,16 \% $\mathrm{P}_{2} \mathrm{O}_{5}$ соответственно. Породный прослой-междупластие, разделяющий пласты XXXа и XXX, содержит 0,88 \% $\mathrm{P}_{2} \mathrm{O}_{5}$. Bce три пробы отличаются также повышенными содержаниями $\mathrm{CaO}(1,58-6,18 \%)$.

Отношение $\mathrm{SiO}_{2}$ к $\mathrm{Al}_{2} \mathrm{O}_{3}$ (алюмокремниевый модуль, АМ) для каолинита составляет 1,18. В исследуемых породных прослоях это соотношение изменяется от 1,79 до 5,01. Пробы, которые имеют наименьшие показатели AM, отличаются также повышенным содержанием $\mathrm{P}_{2} \mathrm{O}_{5}$. Такая закономерность отмечалась для тонштейнов Бейского месторождения черногорской свиты [13].

Согласно обзору Я.Э. Юдовича и М.П. Кетрис, отношение $\mathrm{TiO}_{2}$ к $\mathrm{Al}_{2} \mathrm{O}_{3}$ (титановый модуль, ТМ) является одним из достоверных показателей вклада пирокластики в формирование отложений, в особенности применительно к кислым вулканическим пеплам [14].

В работе Д.А. Спирса и Р. Канариса-Сотириу показано, что величина ТМ, характерная для риолитовой пирокластики, не превышает 0,02, для пирокластики основного состава, наоборот, более 0,06 [15]. Промежуточные значения ТМ свидетельствуют о вкладе вулканического пепла среднего либо щелочного состава.

Титановый модуль широко используется специалистами в качестве вспомогательного критерия при восстановлении исходного состава измененного пеплового материала [16].

Породные прослои пласта XXX характеризуются низкими значениями ТМ. Для тонштейна И-30 величина ТМ составила 0,018, а для И-25 - 0,027 (табл. 4). Таким же низким значением ТМ характеризуется и породный прослой-междупластие И-22 (0,023).

Тонштейны пласта ХХХа отличаются более высокими значениями ТM, нежели пласта XXX. Так, ТМ тонштейна И-17 достигает 0,053, что является наибольшим показателем для изученных прослоев. Тонштейны И-12 и И-6 характеризуются величиной ТМ 0,036 и 0,037 соответственно. Для пород кровли пласта ХХХа (образец И-1) значение ТМ соответствует значению 0,033 .

Эффективным критерием распознавания состава исходного материала тонштейнов могут служить радиоактивные элементы. Торий, как элементгидролизат в среде палеоболота, мигрирует слабо. Уран в этих же условиях восстанавливается до валентности 4+ и также слабо мигрирует. Исходя из этого можно предполагать несущественное выщелачивание и вынос радиоактивных элементов при преобразовании исходной пирокластики и, следовательно, высокие содержания тория и урана могут служить индикаторами кислой и щелочной пирокластики.

Среди изученных прослоев выделилось две группы. В первую группу вошли прослои пласта XXXа (И-6 и И-12). Они отличаются высоким содержанием тория - 27,7 и 24,6 г/т соответственно. Также в них отмечена повышенная концентрация урана: 6,2 г/т 
для И-6 и 7 г/т для И-12. К первой группе относится породный прослой И-22, концентрация тория и урана в котором составляет 30,4 и 9,4 г/т соответствтвенно (табл. 5). В связи с высоким содержанием Th и U paдиоактивность его составляет 25 мкР/ч, что служит отличительным признаком при распозновании его как в разрезе, так и при каротаже скважин. Это свойство позволяет специалистам диагностировать прослои измененной пирокластики в угольных толщах $[17$, $18]$.

Во вторую группу попали прослои пласта XXX (И-25, И-30) с менышей концентрацией радиоактивных элементов, чем в ранее описаных. Так, для прослоя И-25 концентрация Тh составила 8 г/т, a U - 1,9 г/т. Для нижележащего прослоя (И-30) содержание этих же элементов составило: Th - 11,6 г/т, U - 3,5 г/т. Также во вторую группу попал прослой И-17 (пласт $\mathrm{XXXa),} \mathrm{содержание} \mathrm{тория} \mathrm{в} \mathrm{котором} \mathrm{составило}$ 14,5 г/т, а урана - 2,5 г/т. Торий-урановое отношение в изученных пробах колеблется от 3,2 до 5,7 (табл. 5).

Еще одним критерием восстановления состава исходного пеплового материала является диаграмма, основанная на отношении $\mathrm{Zr} / \mathrm{TiO}_{2}$ к Nb/Y [20]. Прослои И-6 и И-12 занимают на классификационной диаграмме поле, соответствующее риодацитам/дацитам. Прослой И-17 также расположен в поле риодацитов/дацитов, но тяготеет к риолитам. Породные прослои И-25 и И-30 соответствуют риолитам. Породный прослой И-22 по этим показателям располагается в поле комендитов/пантеллеритов (рис. 8).

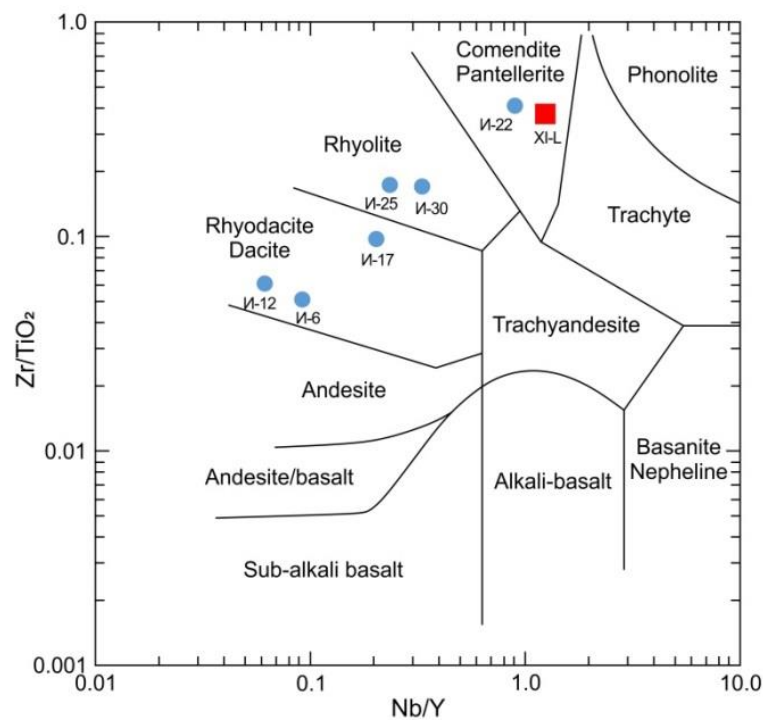

Pис. 8. Положение изученных проб на $\mathrm{Zr} / \mathrm{TiO}_{2}-\mathrm{Nb} / \mathrm{Y}$ диаграмме [20]. XI-L - пирокластический горизонт из пласта ХІ Кузбасса, И - пробы пород ХХХХХХа пластов Минусинского бассейна

Fig. 8. Location of the samples according to classification diagram by $\mathrm{Zr} / \mathrm{TiO}_{2}$ and $\mathrm{Nb} / \mathrm{Y}$ [20]. XI-L pyroclastic layer from the seam XI (Kuznetsk Basin), И - samples from seams XXX-XXXa (Minusinsk Basin)
Таблица 5. Микроэлементы (2/m) в углевмещңающих породах и породных прослоях

Table 5. Trace elements (ppm) in coal-bearing rocks and intraformational seams

\begin{tabular}{|c|c|c|c|c|c|c|c|c|c|}
\hline 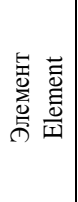 & И-1 & И-6 & И-12 & И-17 & И-22 & И-25 & И-30 & И-36 & 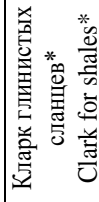 \\
\hline $\mathrm{Li}$ & 25,7 & 51,9 & 64,3 & 33,0 & 95,6 & \begin{tabular}{|l|}
37,7 \\
\end{tabular} & 33,6 & 95,1 & 46 \\
\hline $\mathrm{Be}$ & 1,7 & 2,2 & 2,9 & 13,6 & 4,7 & 7,2 & 4,0 & 1,1 & 2,8 \\
\hline Sc & 10,9 & 5,3 & 4,7 & 7,0 & 8,1 & 5,1 & 1,7 & 1,4 & 15 \\
\hline $\mathrm{V}$ & 121,8 & 20,3 & 15,5 & 55,6 & 29,9 & 25,3 & 12,4 & 3,8 & 120 \\
\hline $\mathrm{Cr}$ & 194,6 & 31,7 & 21,2 & 92,5 & 18,9 & 52,3 & 29,0 & 2,6 & 76 \\
\hline Co & 19,2 & 3,9 & 2,3 & 38,7 & 12,0 & 7,8 & 2,7 & 0,8 & 19 \\
\hline $\mathrm{Ni}$ & 167,5 & 21,2 & 15,5 & 117,6 & 22,5 & \begin{tabular}{|l|}
36,1 \\
\end{tabular} & 10,6 & 4,2 & 47 \\
\hline $\mathrm{Cu}$ & \begin{tabular}{|l|}
33,9 \\
\end{tabular} & 116,2 & \begin{tabular}{|l|}
30,6 \\
\end{tabular} & \begin{tabular}{|l|}
98,0 \\
\end{tabular} & $\begin{array}{l}40,6 \\
\end{array}$ & \begin{tabular}{|l|l}
64,7 \\
\end{tabular} & \begin{tabular}{|l|}
19,7 \\
\end{tabular} & 11,3 & 36 \\
\hline $\mathrm{Zn}$ & 128,4 & 11,3 & 47,3 & 216,5 & 238,4 & 83,3 & 96,8 & 17,1 & 52 \\
\hline $\mathrm{Ga}$ & 15,7 & 31,3 & 35,4 & 17,0 & 64,5 & 23,5 & 28,4 & 29,1 & 16 \\
\hline $\mathrm{Ge}$ & 0,7 & 0,7 & 0,5 & 3,6 & 3,2 & 2,3 & 0,6 & 1,3 & 2 \\
\hline As & 49,4 & 3,4 & 2,3 & 21,2 & 8,8 & 15,7 & 6,1 & 1,1 & 9,3 \\
\hline $\mathrm{Se}$ & 2,6 & 4,6 & 2,3 & 0 & 4,7 & 7,2 & 3,0 & 1,2 & 0,36 \\
\hline $\mathrm{Rb}$ & 49,7 & 14,7 & 29,9 & 23,1 & 22,1 & 34,7 & 96,7 & 10,7 & 130 \\
\hline $\mathrm{Sr}$ & 85,0 & \begin{tabular}{|l|l|}
272,8 \\
\end{tabular} & 235,8 & 206,3 & 149,8 & \begin{tabular}{|l|}
128,9 \\
\end{tabular} & 95,1 & 63,9 & 240 \\
\hline $\mathrm{Y}$ & \begin{tabular}{|l|}
24,7 \\
\end{tabular} & \begin{tabular}{|l|l}
101,1 \\
\end{tabular} & 120,2 & \begin{tabular}{|c|}
95,8 \\
\end{tabular} & \begin{tabular}{|l|}
126,0 \\
\end{tabular} & \begin{tabular}{|l|l|}
287,4 \\
\end{tabular} & 32,6 & 12,1 & 31 \\
\hline $\mathrm{Zr}$ & 120,5 & 151,1 & 119,2 & 372,7 & 1336,6 & 378,1 & 318,6 & 23,2 & 190 \\
\hline $\mathrm{Nb}$ & 11,1 & 6,5 & 6,3 & 20,7 & 113,7 & \begin{tabular}{|l|}
86,8 \\
\end{tabular} & 10,8 & 2,8 & 11 \\
\hline Mo & 3,4 & 1,5 & 1.4 & 19,0 & 2,1 & 11,0 & 2,3 & 1,3 & 1,6 \\
\hline $\mathrm{Cd}$ & 0,6 & 1,5 & 0,5 & 1,4 & 1,8 & 0,5 & 0,0 & 0,1 & 1 \\
\hline $\mathrm{Sn}$ & 2,0 & 8,2 & 7,6 & 7 & 9,4 & 2,8 & 9,0 & 7,7 & 3,5 \\
\hline $\mathrm{Sb}$ & 0,8 & 0,6 & 0,4 & 1,7 & 0,6 & 1,7 & 0,3 & 1,4 & 1 \\
\hline Cs & 5,8 & 2,2 & 1,9 & 6 & 2,4 & 6,2 & 2,0 & 0,8 & 10 \\
\hline $\mathrm{Ba}$ & 329 & 345 & 445 & 535 & 340 & 534 & 998,9 & 137,1 & 460 \\
\hline $\mathrm{La}$ & 32,6 & 29,1 & 15,9 & 125,0 & 129,4 & 288,6 & 105 & \begin{tabular}{|c|}
18,6 \\
\end{tabular} & 48 \\
\hline $\mathrm{Ce}$ & 68,0 & 77,2 & 41,3 & 299 & 286 & 547 & 231 & 40,4 & 75 \\
\hline $\operatorname{Pr}$ & 6,9 & 7,6 & 5,1 & 33,2 & 36,7 & \begin{tabular}{|l}
67,4 \\
\end{tabular} & 23,9 & 4,1 & 10 \\
\hline $\mathrm{Nd}$ & 28,5 & 31,1 & 22,6 & 135,6 & 118,1 & 219,3 & 88,0 & 17,4 & 36 \\
\hline $\mathrm{Sm}$ & 5,8 & 8,3 & 7,4 & 28,6 & 27,4 & 43,1 & 17,3 & 3,4 & 8 \\
\hline $\mathrm{Eu}$ & 1,4 & 1,6 & 1,6 & 3.3 & 2,6 & 3,9 & 1,7 & 0,4 & 1,2 \\
\hline $\mathrm{Gd}$ & 7,6 & 10,3 & 11,6 & 20,7 & 24,7 & \begin{tabular}{|l|}
40,4 \\
\end{tabular} & 12,5 & 3,5 & 5,8 \\
\hline $\mathrm{Tb}$ & 0,8 & 1,4 & 1,8 & 2,8 & 4,1 & 5,9 & 1,7 & 0,4 & 0,8 \\
\hline Dy & 4,8 & 10,1 & 11,7 & 13,6 & 23,0 & 34,2 & 1,7 & 6 & 4,4 \\
\hline Ho & 0,9 & 2,3 & 2,8 & 2,9 & 4,4 & 8,0 & 1,4 & 0,5 & 0,7 \\
\hline $\mathrm{Er}$ & 2,8 & 7,7 & 9,0 & 9,1 & 12,2 & 26,3 & 3,6 & 1,3 & 1,9 \\
\hline $\mathrm{Tm}$ & 0,4 & 1,1 & 1,2 & 1,5 & 1,5 & 3,3 & 4 & 0,2 & 0,6 \\
\hline $\mathrm{Yb}$ & 2,9 & 8,0 & 8,6 & 9,0 & 10,3 & 23,8 & 2,8 & 1 & 2,5 \\
\hline $\mathrm{Lu}$ & 0,5 & 1,2 & 42 & 6 & 16 & 3,7 & 0,4 & 0,1 & 0,4 \\
\hline $\mathrm{Hf}$ & 3,5 & 7,7 & 8,1 & 9,0 & 41,7 & 8,4 & 8,2 & 3,8 & 5 \\
\hline $\mathrm{Ta}$ & 0,91 & 3,0 & 3,3 & 1,5 & 9,7 & 2,0 & 5,2 & 2,0 & 1,4 \\
\hline $\mathrm{W}$ & 1,4 & 0,5 & 0,5 & 5,1 & 2,5 & 1,6 & 0,7 & 0,3 & 2,6 \\
\hline $\mathrm{Au}$ & - & 0,0026 & $<0,002$ & 0,0097 & 0,0043 & 0,0028 & 0,0026 & 0,0030 & 0,0065 \\
\hline $\mathrm{Hg}, \mathrm{ppb}$ & 392 & 141 & 107 & 398 & 190 & 132 & 136 & 24 & 89 \\
\hline $\mathrm{Tl}$ & 0,8 & 0,7 & 0,4 & 1,9 & 0,5 & 1,1 & 0,6 & 0,1 & 1,3 \\
\hline $\mathrm{Pb}$ & 17,1 & 58,3 & 66,6 & 29,6 & 36,8 & 15,0 & 34,5 & 50,2 & 14 \\
\hline $\mathrm{Th}$ & 13,5 & 27,7 & 24,6 & 14,5 & 30,4 & 8,0 & 11,6 & 13,6 & 10 \\
\hline $\mathrm{U}$ & 2,8 & 6,2 & 7,0 & 2,5 & 9,4 & 1,9 & 3,5 & 1,0 & 4,5 \\
\hline$\sum$ Р3Э & 164 & 197 & 142 & 686 & 682 & 1315 & 497 & 94 & 195 \\
\hline $\mathrm{Th} / \mathrm{U}$ & 4,7 & 4,5 & 3,5 & 5,7 & 3,2 & 4,1 & 3,4 & 13,3 & 2,2 \\
\hline
\end{tabular}

Примечание: - нет данных; *-no [19].

Note: - no data; $*$ - by [19]. 
Результаты исследователей показывают, что данная диаграмма имеет ограниченное применение. Это связано с различной миграционной способностью элементов, используемых в диаграмме, что приводит к искажению результатов. В следствии неравномерного перераспределения элементов происходит более активный вынос ниобия и циркония из прослоев, нежели иттрия и титана, что приводит к заниженной оценке значения кислотности и щелочности исходных пород диаграммы [21].

О природе исходного вещества горных пород можно судить по результатам изучения лантаноидов (РЗЭ). Распределение РЗЭ, нормированных на кларк для верхней континентальной земной коры в междупластии (И-22), кровле (И-1) и почве (И-36), различно (рис. 9). Породы почвы имеют характерный для террегенных осадочных отложений график распределения РЗЭ.

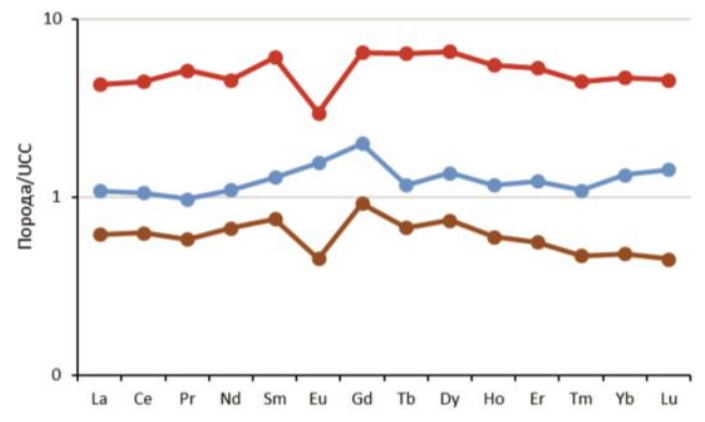

$\rightarrow n-1 \rightarrow n-22 \rightarrow n-36$

Pис. 9. Нормированные графики распределения РЗЭ в междупластии ХХХХ и ХХХ пластов и в породах почвы и кровли. Нормировано на кларк в верхней континентальной земной коре (UCC) [22]

Fig. 9. UCC-normalized REE patterns between the seams $X X X a$ and $X X X$, in the bottom and roof of rock layers. Upper continental crust (UCC) data from [22]

Характер кривых распределения РЗЭ, нормированных к хондриту, в породных прослоях пластов XXX и ХХХа свидетельствует о различном составе формирующего их исходного материала (рис. $10, a$ ).

Отчетливой отрицательной европиевой аномалией характеризуется ряд проб, среди которых: прослой- междупластие (И-22), породы почвы пласта XXX (И-36), а также тонштейны из пласта XXX (И-30, И-25). На различный состав исходного материала породных прослоев в угольных пластах указывает характер нормированных графиков и величина еваропиевого минимума. Европиевый минимум для пород нижней части разреза составляет $\mathrm{Eu} / \mathrm{Eu}^{*}=0,28-0,35$. Тонштейны из залегающего выше угольного пласта ХХХа (пробы И17, И-12, И-6) имеют менее отчетливый европиевый минимум, его величина составляет 0,40-0,53. Эти выводы согласуются с данными изучения $\mathrm{TiO}_{2} / \mathrm{Al}_{2} \mathrm{O}_{3}$ отношения и с положением исследованных проб на диаграмме Винчестера и Флойда (табл. 4, рис. 8), указывающими на более кислый состав пирокластики в нижней части разреза (риолиты-пантеллериты) и более основной для верхней (дациты-риодациты).

Комплекс методов, используемый при реконструкции состава пеплов, из которых сформировался изученный прослой-междупластие (И-22), позволил установить его исходный состав как пантеллеритовый. В одновозрастных углях кемеровской свиты Кузнецкого бассейна известен схожий по геологоминералогическим особенностям породный прослой [8]. На рис. 10, б приведены нормированные на хондрит графики распределения РЗЭ в породах схожего состава. Графики характеризуются отрицательной европиевой аномалией и преобладанием группы легких лантаноидов над тяжелыми.

Европиевый минимум для прослоя-междупластия из Минусинского бассейна составил 0,31 , для прослоя из пласта XI Кузнецкого бассейна - 0,18. Для пантеллеритового туфа из массива Улан-Толгой, европиевый минимум составил 0,1.

Лантан-иттербиевое отношение в изученных прослоях изменяется в широких пределах от 1,9 до 37,4. Наименьшим значением La/Yb характеризуются тонштейны пласта ХХХа И-12 $(1,9)$ и И-6 $(3,6)$. Для прослоев И-25, И-22, И-17 этот показатель колеблется в пределах 12,1-13,9. Наибольшим показателем $\mathrm{La} / \mathrm{Yb}$ характеризуется тонштейн И-30 - 37,4. Для почвы (И-36) и кровли (И-1) лантан-иттербиевое отношение составило 17,6 и 11,1 соответственно.
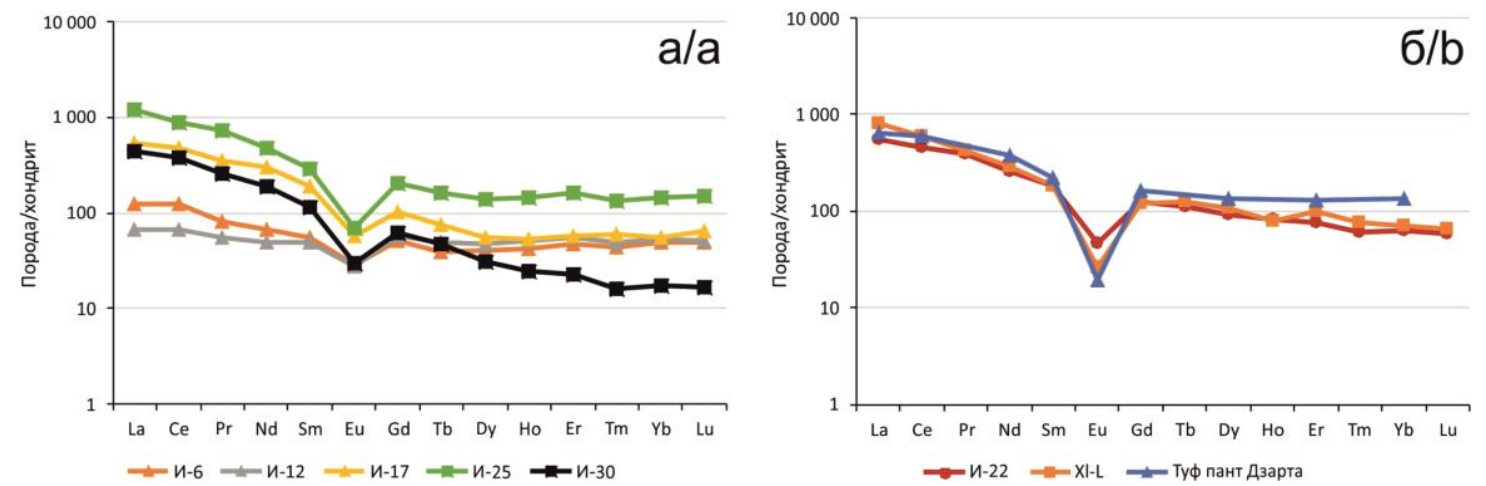

Pис. 10. Нормированные графики распределения РЗЭ: а) в тонштейнах ХХХХ и ХХХХ пластов; б) в породных прослоях Минусинского бассейна, Кузнецкого бассейна и пантеллерите из массива Улан-Толгой, Монголия [24]. Нормировано на хондрит [23]

Fig. 10. Chondrite-normalized REE patterns: a) in tonsteins of the seams XXXa and XXX; b) in intraformational seams of Minusinsk and Kuznetsk basins and pantellerite from Ulan-Tolgoy massif, Mongolia [24]. Chondrite data from [23] 


\section{Заключение}

Угли и внутрипластовые породные прослои в пласте XXX-XXХа Изыхского месторождения Минусинского бассейна характеризуются аномально высокими содержаниями $\mathrm{Zr}, \mathrm{Nb}, \mathrm{Hf}, \mathrm{Ta}, \mathrm{P} 3 Э$ и $\mathrm{Ga} . \mathrm{B}$ золе угля содержание Zr в отдельных пробах достигает 1,4%, $\mathrm{Nb}-0,26 \%$, Hf -164 г/т, Тa - 21,2 г/т, сумма РЗЭ $0,8 \%, \mathrm{Ga}-92$ г/т.

Накопление аномальных концентраций $\mathrm{Zr}-\mathrm{Nb}$-HfТа-РЗЭ и $\mathrm{Ga}$ характерно преимущественно для породного прослоя, разделяющего пласты XXX и ХХХа a также для углей, находящихся на контакте с породным прослоем. Цирконий, ниобий и РЗЭ образуют более контрастные ореолы вблизи партинга, чем тантал, гафний и галлий. Это объясняется различной подвижностью элементов в условиях гипергенеза. Тантал и галлий выделяются слабой способностью к миграции в данных условиях и концентрируются преимущественно в породном прослое либо в углях в непосредственном контакте с ним. Другие рудные элементы концентрируются в большей степени в угле в приконтактовой зоне, а также на удалении от прослоя.

В породах партинга (междупластия) и в углях в приконтактовой зоне выявлены многочисленные новообразованные минералы $\mathrm{Nb}, \mathrm{Zr}$ и РЗЭ. Минералы циркония представлены первичным цирконом, подвергшимся коррозии, и сложными $\mathrm{Nb}-\mathrm{Zr}-\mathrm{P}$ силикатами. Встречаются сложные Nb-Zr-P силикаты, нарастающие на оксидах титана. Среди агрегатов оксида титана были обнаружены разности с примесью $\mathrm{Nb}$.

\section{СПИСОК ЛИТЕРАТУРЫ}

1. Редкометалльный потенциал углей Минусинского бассейна С.И. Арбузов, В.В. Ершов, Л.П. Рихванов, Т.Ю. Усова, В.В. Кяргин, А.А. Булатов, Н.Е. Дубовик. - Новосибирск: Изд-во СО РАН, филиал «Гео», 2003. - 347 с.

2. A new type of $\mathrm{Nb}(\mathrm{Ta})-\mathrm{Zr}(\mathrm{Hf})-\mathrm{REE}-\mathrm{Ga}$ polymetallic deposit in the late Permian coal-bearing strata, eastern Yunnan, southwestern China: Possible economic significance and genetic implications / S. Dai, Y. Zhou, M. Zhang, X. Wang, J. Wang, X. Song, Y. Jiang, Y. Luo, Z. Song, Z. Yang, D. Ren // International Journal of Coal Geology. - 2010. - V. 83. - P. 55-63.

3. Geochemistry of trace elements in Chinese coals: a review of abundances, genetic types, impacts on human health, and industrial utilization / S. Dai, D. Ren, C.-L. Chou, R.B. Finkelman, V.V. Seredin, Y. Zhou // International Journal of Coal Geology. 2012. - V. 94. - P. 3-21.

4. A model for Nb-Zr-REE-Ga enrichment in Lopingian altered alkaline volcanic ashes: Key evidence of H-O isotopes / S. Dai, V.P. Nechaev, I.Y. Chekryzhov, L. Zhao, S.V. Vysotskiy, I. Graham, C.R. Ward, A.V. Ignatiev, T.A. Velivetskaya, L. Zhao, D. French, J.C. Hower // Lithos. - 2018. - V. 302-303. P. 359-369.

5. Geological controls on enrichment of $\mathrm{Mn}, \mathrm{Nb}(\mathrm{Ta}), \mathrm{Zr}(\mathrm{Hf})$, and REY within the Early Permian coals of the Jimunai Depression, Xinjiang Province, NW China / B. Li, X. Zhuang, X. Querol, J. Li, N. Moreno, P. Córdoba, Y. Shangguan, J. Zhou, X. Ma, S. Liu // International Journal of Coal Geology. - 2019. - V. 215. - Article 103298.

6. Середин В.В. Первые данные об аномальных концентрациях ниобия в углях России // Доклады академии наук. - 1994. Т. 335. - № 5. - С. 634-636.

7. Арбузов С.И., Ершов В.В. Геохимия редких элементов в углях Сибири. - Томск: ИД «Д-Принт», 2007. - 468 с.

8. Geochemistry, mineralogy and genesis of rare metal (Nb-Ta-ZrHf-Y-REE-Ga) coals of the seam XI in the south of Kuznetsk
Согласно полученным данным на накопление редких металлов в угле изыхской свиты повлияла вулканогенная пирокластика кислого и щелочного (риолитпантеллеритового) состава. Исходным материалом, послужившим для формирования породного прослоя в углях, мог быть вулканический пепел, перенесенный из удаленного источника. По составу исходный материал пород прослоя-междупластия соответствует пантеллеритовым туфам. На территории сибирского региона схожими геохимическим чертами того же временного периода обладает угольный пласт XI кемеровской свиты Кузнецкого угольного бассейна с пепловым материалом пантеллеритового состава [8]. Особенности химического состава этих внутриугольных породных прослоев, состава минеральных новообразований в прослоях и в углях на контакте с ними позволяют идентифицировать их как аналоги. Их сходство подтверждают и различные геохимические критерии: положение на диаграмме Винчестера и Флойда, $\mathrm{TiO}_{2} / \mathrm{Al}_{2} \mathrm{O}_{3}$ отношение, особенности распределения лантаноидов. По характеру нормированной кривой прослои практически идентичны.

Полученные данные указывают на масштабное проявление кислого и щелочного вулканизма в период накопления изыхской и кемеровской свит раннепермского времени и расширяют перспективы выявления масштабного Zr-Nb-Hf-Ta-P3Э-Ga оруденения на территории Северной Азии.

Исследование выполнено при финансовой поддержке РФФИ в рамках научного проекта № 19-35-90010

Basin, Russia / S.I. Arbuzov, D.A. Spears, A.V. Vergunov, S.S. Ilenok, A.M. Mezhibor, V.P. Ivanov, N.A. Zarubina // Ore Geology Reviews. - 2019. - V. 113. - Article 103073.

9. Угольная база России. Т. 3. Угольные бассейны и месторождения Восточной Сибири / под ред. В.Ф. Череповского. - М.: ООО «Геоинформцентр», 2002. $-488 \mathrm{c}$.

10. Государственная геологическая карта РФ. Масштаб 1:1000000 (третье поколение). Серия Алтае-Саянская. Лист N46 - Абакан. - СПб.: Картфабрика Всероссийского научноисследовательского геологического института, 2008.

11. Ketris M.P., Yudovich Ya.E. Estimations of Clarkes for Carbonaceous biolithes: World average for trace element contents in black shales and coals // International Journal of Coal Geology. - 2009. - V. 78. - P. 135-148.

12. Spears D.A., Arbuzov S.I. A geochemical and mineralogical update on two major tonsteins in the UK Carboniferous Coal Measures // International Journal of Coal Geology. - 2019. V. 210. - Article 103199.

13. Вергунов А.В., Арбузов С.И., Соболенко В.М. Минералогия и геохимия тонштейнов в углях Бейского месторождения Минусинского бассейна // Известия Томского политехнического университета. Инжиниринг георесурсов. - 2019. - Т. 330. № 2. - C. $155-166$.

14. Юдович Я.Э., Кетрис М.П. Основы литохимии. - СПб: Наука, 2000. $-479 \mathrm{c}$

15. Spears D.A., Kanaris-Sotiriou R. A geochemical and mineralogical investigation of some British and other European tonsteins // Sedimentology. - 1979. - V. 26. - P. 407-425.

16. Altered volcanic ashes in coal and coal-bearing sequences: A review of their nature and significance / S. Dai, C.R. Ward, I.T. Graham, D. French, J.C. Hower, L. Zhao, X. Wang // EarthScience Reviews. - 2017. - V. 175. - P. 44-74.

17. Spears D.A. The origin of tonsteins, an overview, and links with seatearths, fireclays and fragmental clay rocks // International Journal of Coal Geology. - 2012. - V. 94. - P. 22-31. 
18. Chemical and mineralogical compositions of silicic, mafic, and alkali tonsteins in the late Permian coals from the Songzao Coalfield, Chongqing, Southwest China / S. Dai, X. Wang, Y. Zhou, J.C. Hower, D. Li, W. Chen, X. Zhu, J. Zou // Chemical Geology. - 2011. - V. 282. - P. 29-44.

19. Grigorev N.A. Average concentrations of chemical elements in rocks of the upper continental crust // Geochemistry International. - 2003. - V. 41. - № 7. - P. 711-718.

20. Winchester J.A., Floyd P.A. Geochemical discrimination of different magma series and their differentiation products using immobile elements // Chemical Geology. - 1977. - V. 20. P. $325-343$.

21. Минералого-геохимическая идентификация продуктов эксплозивного вулканизма в углях Минусинского бассейна С.И. Арбузов, С.С. Ильенок, А.В. Вергунов, М.В. Шалдыбин, В.М. Соболенко, П.Е. Некрасов // Петрология магматических и метаморфических комплексов. Вып. 9. Материалы IX Bсе- российской петрографической конференции с международным участием. - Томск: Изд-во Томского ЦНТИ, 2017. C. $35-37$.

22. Taylor S.R., McLennan S.M. The continental crust: its composition and evolution. - Oxford: Blackwell Scientific, 1985. $-312 \mathrm{p}$.

23. McDonough W.F., Sun S.-s. The composition of the Earth // Chemical Geology. - 1995. - V. 120. - P. 223-253.

24. Состав, источники и механизмы формирования редкометальных гранитоидов позднепалеозойской Восточно-Саянской зоны щелочного магматизма (на примере массива УланТологой) / В.В. Ярмолюк, Д.А. Лыхин, А.М. Козловский, А.В. Никифоров, А.В. Травин // Петрология. - 2016. - Т. 24. № 5. - C. 515-536.

Поступила 19.02.2020 г.

\section{Информация об авторах}

Вергунов A.B., аспирант, инженер-исследователь отделения геологии Инженерной школы природных ресурсов Национального исследовательского Томского политехнического университета.

Арбузов С.И., доктор геолого-минералогических наук, профессор отделения геологии Инженерной школы природных ресурсов Национального исследовательского Томского политехнического университета.

Epeмeева B.B., магистрант отделения геологии Инженерной школы природных ресурсов Национального исследовательского Томского политехнического университета. 
UDC 553.493:550.42

\title{
MINERALOGY, GEOCHEMISTRY AND GENESIS OF RARE METAL Zr-Nb-Hf-Ta-REE-Ga MINERALIZATION OF THE SEAM XXX OF MINUSINSK BASIN
}

\author{
Alexey V. Vergunov'1, \\ alexeivergunov@rambler.ru \\ Sergey l. Arbuzov ${ }^{1}$, \\ siarbuzov@mail.ru \\ Vlada V. Eremeeva 1 \\ vlada.eremeeva1996@yandex.ru \\ ${ }^{1}$ National Research Tomsk Polytechnic University, \\ 30, Lenin avenue, Tomsk, 634050, Russia.
}

The relevance of the research is caused by the demand for assessment of volcanic pyroclastic material influence on formation of rare elements geochemical background in coal.

The main aim of the research is to identify mineral and geochemical characteristics of coals and surrounding rocks in the seam XXX of Minusinsk coal basin.

Objects: coals and surrounding rocks in the seam XXX of Minusinsk coal basin.

Methods: sampling of the seam XXX of Minusinsk coal basin; chemical composition is identified with inductively coupled plasma massspectrometry (ICP-MS), inductively coupled plasma atomic emission spectrometry (ICP-AES), instrumental neutron activation analysis (INAA): mineral composition is investigated with optical microscopy, petrographic methods, scanning electron microscopy, $X$-ray diffractometry.

Results. The detailed mineral and geochemical investigations of rare-metal Zr-Nb-Hf-Ta-REE-Ga mineralization in the seam XXX-XXXa, Izykh coal deposit, Minusinsk basin were carried out. In coal ash maximum content of $\mathrm{Zr}$ is 1,4\%, Nb-0,26\%, Hf - $164 \mathrm{ppm}$, Ta $21,2 \mathrm{ppm}, \sum R E E-0,8 \%, \mathrm{Ga}-226 \mathrm{ppm}$. The ore matter is predominantly concentrated in the fine mineral phases, composed mainly of $\mathrm{Zr}-\mathrm{Nb}$-Ti-Fe oxides, complex Nb-Zr-P silicates, rare-earth phosphates (monazite, xenotime). The relation between the anomalous concentrations of rare metals and the intraformational seam was established. The main mineral in the intraformational seam is kaolinite (68,9\%), quartz (11,0\%), K-feldspars (7,0\%), and albite (5,6\%) occur less often. This seam has volcanogenic pyroclastics genesis, and its composition is pantellerite-comendite. The intraformational seam enriched with similar rare-metal mineralization was found earlier in coals of Kemerovskaya suite (Kuznetsk coal basin). Complex Zr-Nb-Hf-Ta-REE-Ga mineralization associated with the volcanogenic pyroclastics in coals of both Kuznetsk and Minusinsk basins is an evidence of possible global felsic and alkaline volcanic activity during coal formation and expands the prospects of revealing further such mineralization in Permian coals of other basins.

\section{Key words:}

Coal, coal basin, rare metal mineralization, volcanogenic pyroclastic, Minusinsk basin.

The reported study was funded by RFBR, project number 19-35-90010.

\section{REFERENCES}

1. Arbuzov S.I. Ershov V.V., Rikhvanov L.P., Usova T.Y, Kargin V.V., Bulatov A.A., Dubovik N.E. Redkometallny potentsial ugley Minusinskogo basseyna [Rare-metal potential of the coals of the Minusinsk basin]. Novosibirsk, SO RAN Publ., 2003. $347 \mathrm{p}$.

2. Dai S., Zhou Y., Zhang M., Wang G.X., Wang J., Song X., Jiang Y., Luo Y., Song Z., Yang Z., Ren D. A new type of $\mathrm{Nb}(\mathrm{Ta})-\mathrm{Zr}(\mathrm{Hf})-\mathrm{REE}-\mathrm{Ga}$ polymetallic deposit in the late Permian coal-bearing strata, eastern Yunnan, southwestern China: Possible economic significance and genetic implications. International Journal of Coal Geology, 2010, vol. 83, pp. 55-63.

3. Dai S., Ren D., Chou C.-L., Finkelman R.B., Seredin V.V., Zhou Y. Geochemistry of trace elements in Chinese coals: a review of abundances, genetic types, impacts on human health, and industrial utilization. International Journal of Coal Geology, 2012, vol. 94, pp. 3-21.

4. Dai S., Nechaev V.P., Chekryzhov I.Yu., Zhao L., Vysotskiy S.V., Graham I., Ward C.R., Ignatiev A.V., Velivetskaya T.A., Zhao L., French D., Hower J.C. A model for Nb-Zr-REE-Ga enrichment in Lopingian altered alkaline volcanic ashes: key evidence of $\mathrm{H}-\mathrm{O}$ isotopes. Lithos, 2018, vol. 302-303, pp. 359-369.

5. Li B., Zhuang X., Querol X., Li J., Moreno N., Córdoba P., Shangguan Y., Zhou J., Ma X., Liu S. Geological controls on enrichment of $\mathrm{Mn}, \mathrm{Nb}(\mathrm{Ta}), \mathrm{Zr}(\mathrm{Hf})$, and REY within the Early Permian coals of the Jimunai Depression, Xinjiang Province, NW
China. International Journal of Coal Geology, 2019, vol. 215, article 103298

6. Seredin V.V. Pervye dannye ob anomalnykh kontsentratsiyakh niobiya $\mathrm{v}$ uglyakh Rossii [The first data on abnormal concentrations of niobium in coals of Russia]. Doklady akademii nauk, 1994, vol. 335, no. 5, pp. 634-636.

7. Arbuzov S.I., Ershov V.V. Geokhimiya redkikh elementov v uglyakh Sibiri [Geochemistry of rare elements in coals of Siberia]. Tomsk, D-Print Publ. house, 2007. 468 p.

8. Arbuzov S.I., Spears D.A., Vergunov A.V., Ilenok S.S., Mezhibor A.M., Ivanov V.P., Zarubina N.A. Geochemistry, mineralogy and genesis of rare metal (Nb-Ta-Zr-Hf-Y-REE-Ga) coals of the seam XI in the south of Kuznetsk Basin, Russia. Ore Geology Reviews, 2019, vol. 113, article 103073.

9. Ugolnaya baza Rossii. T. 3. Ugolnye basseyny i mestorozhdeniya Vostochnoy Sibiri [Coal base of Russia. Vol. III. Coal basins and deposits of Eastern Siberia]. Ed. by V.F. Cherepovskiy. Moscow, Geoinformtsentr Publ., 2002. 488 p.

10. Gosudarstvennaya geologicheskaya karta RF. Masshtab 1:1000000 (tretye pokolenie). Seriya Altaye-Sayanskaya. List N46, Abakan [State geological map of the Russian Federation. Scale 1:1000000 (third generation). Series Altai-Sayan. Sheet N-46, Abakan]. St-Petersburg, Cartridge factory Russian Geological Research Institute, 2008.

11. Ketris M.P., Yudovich Ya.E. Estimations of Clarkes for Carbonaceous biolithes: World average for trace element contents 
in black shales and coals. International Journal of Coal Geology, 2009, vol. 78, pp. 135-148.

12. Spears D.A., Arbuzov S.I. A geochemical and mineralogical update on two major tonsteins in the UK Carboniferous Coal Measures. International Journal of Coal Geology, 2019, vol. 210, article 103199 .

13. Vergunov A.V., Arbuzov S.I., Sobolenko V.M. Mineralogy and geochemistry of tonsteins in the Beysk coal deposit of the Minusinsk coal basin. Bulletin of the Tomsk Polytechnic University. Geo Assets Engineering, 2019, vol. 330 no. 2, pp. 155166. In Rus.

14. Yudovich Ya.E., Ketris M.P. Osnovy litohimii [Foundations of lithochemistry]. St-Petersburg, Science Publ., 2000. 479 p.

15. Spears D.A., Kanaris-Sotiriou R. A geochemical and mineralogical investigation of some British and other European tonsteins. Sedimentology, 1979, vol. 26, pp. 407-425.

16. Dai S., Ward C.R., Graham I.T., French D., Hower J.C., Zhao L., Wang X. Altered volcanic ashes in coal and coal-bearing sequences: a review of their nature and significance. Earth-Science Reviews, 2017, vol. 175, pp. 44-74.

17. Spears D.A. The origin of tonsteins, an overview, and links with seatearths, fireclays and fragmental clay rocks. International Journal of Coal Geology, 2012, vol. 94, pp. 22-31.

18. Dai S., Wang X., Zhou Y., Hower J.C., Li D., Chen W., Zhu X., Zou J. Chemical and mineralogical compositions of silicic, mafic, and alkali tonsteins in the late Permian coals from the Songzao Coalfield, Chongqing, Southwest China. Chemical Geology, 2011, vol. 282 , pp. $29-44$

19. Grigorev N.A. Average concentrations of chemical elements in rocks of the upper continental crust. Geochemistry International, 2003, vol. 41, no. 7, pp. 711-718.

\section{Information about the authors}

Alexey V. Vergunov, post-graduate student, research engineer, National Research Tomsk Polytechnic University.

Sergey I. Arbuzov, Dr. Sc., professor, National Research Tomsk Polytechnic University.

Vlada V. Eremeeva, graduate student, National Research Tomsk Polytechnic University.
20. Winchester J.A., Floyd P.A. Geochemical discrimination of different magma series and their differentiation products using immobile elements. Chemical Geology, 1977, vol. 20, pp. 325-343.

21. Arbuzov S.I., Ilenok S.S., Vergunov A.V., Shaldybin M.V., Sobolenko V.M., Nekrasov P.E. Mineralogo-geokhimicheskaya identifikatsiya produktov eksplozivnogo vulkanizma $\mathrm{v}$ uglyakh Minusinskogo basseyna [Mineralogical and geochemical identification of products of explosive volcanism in the coals of the Minusin basin]. Petrologiya magmaticheskikh $i$ metamorficheskikh kompleksov. Vyp. 9 Materialy IX Vserossiyskoy petrograficheskoy konferentsii $s$ mezhdunarodnym uchastiyem [Petrology of magmatic and metamorphic complexes. Iss. 9 Materials of the IX All-Russian Petrographic Conference with international participation]. Tomsk, Tomsk scientific and technical information center Publ., 2017. pp. 35-37.

22. Taylor S.R., McLennan S.M. The continental crust: its composition and evolution. Oxford, Blackwell Scientific, 1985. $312 \mathrm{p}$.

23. McDonough W.F., Sun S.-s. The composition of the Earth. Chemical Geology, 1995, vol. 120, pp. 223-253.

24. Yarmolyuk V.V., Kozlovsky A.M., Nikiforov A.V., Travin A.V., Lykhin D.A. Composition, sources, and mechanisms of origin of rare-metal granitoids in the late Paleozoic Eastern Sayan zone of alkaline magmatism: a case study of the Ulaan Tolgoi massif. Petrology, 2016, vol. 24, no. 5, pp. 477-496.

Received: 19 February 2020. 